\title{
The importance of mixed-phase and ice clouds for climate sensitivity in the global aerosol-climate model ECHAM6-HAM2
}

\author{
Ulrike Lohmann and David Neubauer \\ Institute for Atmospheric and Climate Science, ETH Zurich, Zurich, Switzerland \\ Correspondence: Ulrike Lohmann (ulrike.lohmann@env.ethz.ch)
}

Received: 29 January 2018 - Discussion started: 14 February 2018

Revised: 9 June 2018 - Accepted: 11 June 2018 - Published: 22 June 2018

\begin{abstract}
How clouds change in a warmer climate remains one of the largest uncertainties for the equilibrium climate sensitivity (ECS). While a large spread in the cloud feedback arises from low-level clouds, it was recently shown that mixed-phase clouds are also important for ECS. If mixedphase clouds in the current climate contain too few supercooled cloud droplets, too much ice will change to liquid water in a warmer climate. As shown by Tan et al. (2016), this overestimates the negative cloud-phase feedback and underestimates ECS in the CAM global climate model (GCM). Here we use the newest version of the ECHAM6-HAM2 GCM to investigate the importance of mixed-phase and ice clouds for ECS.

Although we also considerably underestimate the fraction of supercooled liquid water globally in the reference version of the ECHAM6-HAM2 GCM, we do not obtain increases in ECS in simulations with more supercooled liquid water in the present-day climate, different from the findings by Tan et al. (2016). We hypothesize that it is not the global supercooled liquid water fraction that matters, but only how well low- and mid-level mixed-phase clouds with cloud-top temperatures in the mixed-phase temperature range between 0 and $-35^{\circ} \mathrm{C}$ that are not shielded by higher-lying ice clouds are simulated. These occur most frequently in midlatitudes, in particular over the Southern Ocean where they determine the amount of absorbed shortwave radiation. In ECHAM6-HAM2 the amount of absorbed shortwave radiation over the Southern Ocean is only significantly overestimated if all clouds below $0^{\circ} \mathrm{C}$ consist exclusively of ice. Only in this simulation is ECS significantly smaller than in all other simulations and the cloud optical depth feedback is the dominant cloud feedback. In all other simulations, the cloud optical depth feedback is weak and changes in cloud feedbacks associated with cloud
\end{abstract}

amount and cloud-top pressure dominate the overall cloud feedback. However, apart from the simulation with only ice below $0{ }^{\circ} \mathrm{C}$, differences in the overall cloud feedback are not translated into differences in ECS in our model. This insensitivity to the cloud feedback in our model is explained with compensating effects in the clear sky.

\section{Introduction}

Changes in clouds remain one of the largest uncertainties for the calculation of the response of the climate system to a given radiative forcing $\Delta F$ (Dufresne and Bony, 2008). This response can be described with the following equation:

$\Delta F=\Delta R+\Delta H+\lambda \Delta T_{\mathrm{s}}$.

Here $\Delta R$ represents the net radiative imbalance at the top of the atmosphere (TOA), $\Delta H$ is the heat taken up by the ocean, $\Delta T_{\mathrm{s}}$ is the net change in global annual mean surface temperature, and $\lambda$ is the climate feedback parameter in $\mathrm{W} \mathrm{m}^{-2} \mathrm{~K}^{-1} . \Delta R$ and $\Delta T_{\mathrm{S}}$ change over time. In addition, some studies suggest that the heat uptake by the ocean is also time dependent and even $\lambda$ is not a constant parameter (e.g., Knutti and Rugenstein, 2015).

Here we evaluate the increase in $\Delta T_{\mathrm{s}}$, which results from a doubling of carbon dioxide $\left(\mathrm{CO}_{2}\right)$ with respect to preindustrial concentrations, i.e., from a $\Delta F_{2 \times \mathrm{CO}_{2}}$ on the order of $3.7 \mathrm{~W} \mathrm{~m}^{-2}$ (Solomon et al., 2007). There are two metrics that describe the temperature response to a doubling of $\mathrm{CO}_{2}$, the transient climate response (TCR) and the equilibrium climate sensitivity (ECS). TCR is estimated at the time of $\mathrm{CO}_{2}$ doubling from atmosphere global climate model (GCM) simulations in which the $\mathrm{CO}_{2}$ concentration increases by 
$1 \% \mathrm{yr}^{-1}$ and that are coupled to a dynamic ocean (e.g., Flato et al., 2013). ECS is obtained from coupled atmosphereocean simulations that are abruptly exposed to a $\mathrm{CO}_{2}$ doubling relative to preindustrial concentrations and then run until a new equilibrium of the climate system has been established. This requires coupling of the atmosphere GCM to a fully coupled dynamic ocean model (e.g., Gregory et al., 2004; Flato et al., 2013). As such a coupled system takes a long time to reach a new equilibrium, sometimes ECS is approximated from coupled atmosphere-mixed-layer ocean (MLO) climate models (e.g., Meehl et al., 2007; Randall et al., 2007).

ECS can also be determined from the so-called Gregory method (Gregory et al., 2004), in which the TOA radiative flux is regressed against the annual global averaged surface air temperature change. While TCR is more relevant to present-day climate change because it is obtained from transient simulations that at the time of $\mathrm{CO}_{2}$ doubling have not reached a new equilibrium climate, it is more expensive to calculate because it requires fully coupled atmosphere-ocean model simulations over the whole period. Therefore we focus on ECS from coupled atmosphere-MLO simulations in this paper. At the time of the new equilibrium in the, $\Delta R$ and $\Delta H$ vanish and Eq. (1) reduces to

$\Delta F_{2 \times \mathrm{CO}_{2}}=\lambda \Delta T_{\mathrm{s}}$,

and $\Delta T_{\mathrm{S}}$ equals the ECS. $\lambda$ can be decomposed into different feedbacks (e.g., Soden et al., 2008; Shell et al., 2008). $\lambda$ is the sum of the Planck feedback, the water vapor feedback, the lapse rate feedback, the surface albedo feedback, the cloud feedback $\lambda_{c}$, that will be discussed further below, and a residual term (Shell et al., 2008). The residual term considers the interactions among the different components, nonlinear dependencies of ECS from the forcing (Vial et al., 2013) and errors in the radiative kernel method (Shell et al., 2008). This term needs to be small for the decomposition into individual feedbacks to explain the vast majority of the feedback. The average $\lambda$ value from the GCMs that participated in the Coupled Model Intercomparison Project Phase 5 (CMIP5) is $1.1 \mathrm{~W} \mathrm{~m}^{-2} \mathrm{~K}^{-1}$ with a $90 \%$ uncertainty range of $\pm 0.5 \mathrm{~W} \mathrm{~m}^{-2} \mathrm{~K}^{-1}$ (Flato et al., 2013). The uncertainty in $\lambda$ induces the uncertainty in ECS. Neither the average ECS of approximately $3 \mathrm{~K}$ (Collins et al., 2013) nor its uncertainty has changed much over time.

In a first model intercomparison paper by Cess et al. (1989), the estimates of ECS in GCMs varied between 1.4 and $4.1 \mathrm{~K}$. Estimates from the GCMs used in CMIP5 are somewhat higher with 2.1 and $4.7 \mathrm{~K}$ (Forster et al., 2013; Flato et al., 2013), but the range in estimates remains similar. One of the prime contributors to this range in uncertainty are inter-model differences in the low-level shortwave cloud feedback (Yokohata et al., 2010). While the overall cloud feedback is positive with $0.3 \mathrm{~W} \mathrm{~m}^{-2} \mathrm{~K}^{-1}$, the spread in $\lambda_{\mathrm{c}}$ is larger than that of the overall climate feedback parameter and varies by $\pm 0.7 \mathrm{~W} \mathrm{~m}^{-2} \mathrm{~K}^{-1}$ between the CMIP5 models (Flato et al., 2013). This means a negative $\lambda_{c}$ cannot be ruled out and the careful conclusion from the Fifth Assessment Report of the Intergovernmental Panel on Climate Change (IPCC AR5) was that $\lambda_{c}$ is likely (with a probability of $66 \%$ ) positive. Contributors to the positive net cloud feedback are a poleward shift of the midlatitude storms and decreases in the coverage of low-level clouds, both of which result in less scattering of solar radiation (Boucher et al., 2013). Another positive cloud feedback that operates mainly in the longwave radiation regime is the increase in the height of deep convective outflow. Because the troposphere warms but the cloud-top temperature remains at roughly the same temperature (fixed anvil temperature; Hartmann and Larson, 2002), the rate of longwave emission to space from these cloud tops does not keep pace with that of the underlying atmosphere, causing more longwave radiation to remain in the Earth-atmosphere system.

One of the more uncertain cloud feedbacks is the negative cloud optical depth (COD) feedback (e.g., Mitchell et al., 1989; Gordon and Klein, 2014; McCoy et al., 2015; Ceppi et al., 2016). The $\operatorname{COD}(\tau)$ is proportional to the cloud water path over the effective cloud particle size. Therefore changes in $\tau$ can occur due to changes in the cloud water path, which in turn originate from changes in the hydrological cycle, changes in the size of the cloud droplets and ice crystals and changes in cloud phase from ice to water or vice versa. The negative COD feedback is related to a shift from cloud ice in the present-day climate to cloud liquid water at the same altitude in the warmer climate. Because cloud droplets are generally smaller and more numerous than ice crystals and they have a different refractive index, the optical depth of liquid clouds is larger than that of ice clouds for a constant cloud water path. Precipitation formation is also less efficient for liquid clouds than for ice clouds (e.g., Lohmann, 1996; Hoose et al., 2008), further increasing cloud lifetime and $\tau$ of liquid clouds. If, in addition, the cloud water path increases in a warmer climate, $\tau$ will be further enlarged. All of these aspects result in a negative COD feedback.

Tan et al. (2016) analyzed the ratio of supercooled liquid water to the sum of cloud liquid water and cloud ice (supercooled liquid fraction, SLF) between 0 and $-35^{\circ} \mathrm{C}$ in the CAM5 GCM. They found SLF to be systematically underestimated with respect to CALIOP observations, i.e., too much condensate to be in the form of ice at these temperatures. This led to a too negative cloud-phase feedback and in the CAM5 GCM to a too low ECS. When constraining the present-day SLF by satellite observations, their ECS increased by up to $1.3^{\circ} \mathrm{C}$. A similar increase in ECS of $1.5^{\circ} \mathrm{C}$ was found by Frey and Kay (2017) when increasing the fraction of supercooled liquid clouds over the Southern Ocean. Terai et al. (2016) analyzed the low-COD feedback from eight CMIP5 models with that inferred from ISCCP, MODIS, and PATMOS satellite data. They also concluded that the low-COD feedback is likely too negative at mid and high latitudes in climate models. Motivated by these studies and to under- 
stand how universal the findings of the change in ECS using extreme assumptions about the liquid water/ice phase in mixed-phase clouds of Tan et al. (2016) are, here we use the ECHAM6-HAM2 GCM to calculate the impact of mixedphase and ice clouds on ECS.

\section{Description of the model and the sensitivity studies}

In this paper we use the latest version of the aerosol-climate model ECHAM6.3-HAM2.3, which assembles the most recent versions of the atmospheric general circulation model ECHAM (namely ECHAM6, as described in Stevens et al. (2013) with the most recent changes described below) and the aerosol module HAM based on the HAM2 version as described in Zhang et al. (2012), Neubauer et al. (2014), and Schultz et al. (2018) and summarized below. As our simulations are conducted with monthly mean oxidant fields instead of with interactive chemistry as in HAMMOZ (Schultz et al., 2018), we refer to it as ECHAM6-HAM2.

\subsection{ECHAM6}

ECHAM6 is the latest generation of the atmospheric general circulation model developed by the Max Planck Institute for Meteorology (Stevens et al., 2013). Like its predecessors, ECHAM6 employs a spectral transform dynamical core and a flux-form semi-Lagrangian tracer transport algorithm from Lin and Rood (1996). Vertical mixing occurs through turbulent mixing, moist convection (including shallow, deep, and mid-level convection), and momentum transport by gravity waves arising from boundary effects or atmospheric disturbances. Sub-grid-scale cloudiness (stratiform clouds) is represented using the scheme of Sundqvist et al. (1989), which diagnostically calculates the grid cell cloud fraction as a function of the relative humidity in a given grid cell, once a threshold value is exceeded. Cloud liquid water and cloud ice mixing ratios are treated prognostically following Lohmann and Roeckner (1996). In ECHAM6-HAM2, additional prognostic equations for the number concentrations of cloud droplets and ice crystals are included (Lohmann et al., 2007). The two-moment cloud microphysics scheme and the aerosol scheme are described in Sect. 2.2. Radiative transfer in ECHAM6 is represented using the radiation transfer broadband model PSrad (Pincus and Stevens, 2013), which considers 14 and 16 bands for the shortwave (820 to $50000 \mathrm{~cm}^{-1}$ ) and longwave (10 to $3000 \mathrm{~cm}^{-1}$ ) parts of the spectrum, respectively (Iacono et al., 2008).

Radiative transfer is computed based on the amount of gases, aerosols, and clouds in the atmosphere and their related optical properties. Trace gas concentrations of longlived greenhouse gases are specified in the model. Optical properties of aerosol particles and clouds are precalculated for each band of the RRTMG scheme using Mie theory offline and they read from a look-up table based on the con- centration of cloud droplets and ice crystals as computed by the two-moment scheme.

ECHAM6 includes a new land-surface model JSBACH (Reick et al., 2013). JSBACH assumes that each grid box is composed of two fractions, one representing bare soil and the other being covered with vegetation, this one being further subdivided into tiles, one for each of the 11 plant functional types distinguished in JSBACH. Soil hydrology is represented with a single-layer bucket model. A new treatment of the surface albedo (Brovkin et al., 2013) is included, which accounts for the different sections of bare and vegetated areas.

In addition to the improved representation of solar radiative transfer by the RRTMG scheme and the improved surface albedo, smaller changes are included. The vertical discretization within the troposphere (in particular in the upper troposphere and lower stratosphere) is slightly different, the representation of convective triggering has been improved, and the tuning of various model parameters was adjusted. In contrast to ECHAM5, ECHAM6 is more commonly used in a middle-atmosphere configuration, i.e., with the two verticals grids L47 and L95 that resolve the atmosphere from the surface up to $0.01 \mathrm{hPa}$ (roughly $80 \mathrm{~km}$ ).

Changes from ECHAM6.1, as coupled to HAM2 in Neubauer et al. (2014), to ECHAM6.3 used here include small changes in convection, in the middle atmosphere, improvements in snow and sea ice coverage, an improved aerosol climatology (Kinne et al., 2013) combined with a simple plume implementation of anthropogenic aerosols (Stevens et al., 2017), and an improved submodel interface. ECHAM6.3 uses the Monte Carlo independent column approximation radiation scheme with the option for spectral sampling in time (Pincus and Stevens, 2013). The land model JSBACH has been updated with an improved hydrology and soil model. Changes in the cloud cover scheme were made to improve cloud cover in stratocumulus regions. ECHAM6.1 suffered from artificial cloud blinking that occurred due to a bug in the cloud cover scheme, causing the (fractional) cloud cover to be either 0 or 1 . This cloud blinking has been removed in ECHAM6.3.

As in previous versions of ECHAM-HAM, ECHAM drives the aerosol and chemistry modules through the generic sub-model interface by providing meteorological conditions such as wind, temperature, pressure, specific humidity, and conditions pertaining to the land surface (taken from JS$\mathrm{BACH}$ ) such as leaf area index. Aerosol particles and their precursors are transported in the same way as water vapor and cloud species.

\subsection{Aerosol and cloud microphysics scheme}

The aerosol module HAM predicts the evolution of an aerosol ensemble considering five components: sulfate, black carbon, particulate organic matter, sea salt, and mineral dust. The aerosol spectrum is described by the superposition of 
seven log-normal modes ranging from 0.005 to $>0.5 \mu \mathrm{m}$. Aerosol particles within a mode are assumed to be internally mixed, in the sense that each particle can consist of multiple components. Aerosols of different modes are externally mixed, meaning that they coexist in the atmosphere as independent particles. The seven modes of the aerosol number distribution are grouped into four geometrical size classes, including the nucleation, Aitken, accumulation, and coarse modes. Particles in four of the modes contain at least one soluble compound; thus they can take up water and are referred to as soluble. The particles in the other three modes consist of compounds with no or low water solubility and are referred to as insoluble. Through aging processes, insoluble particles can become soluble. Each mode of the aerosol size number distribution is described by the three moments, the aerosol number $N$, the number median radius $r$, and the standard deviation $\sigma$. The standard deviation is assumed to be constant and is set to 1.59 for the nucleation, Aitken, and accumulation modes and to 2 for the coarse modes. The median radius of each mode is calculated from the aerosol number and aerosol mass, which are transported as tracers. For more details, please refer to the description of HAM in Stier et al. (2005) and Zhang et al. (2012).

The two-moment cloud microphysics scheme that predicts the number concentrations and mass mixing ratios of cloud droplets and ice crystals in stratiform clouds as implemented in ECHAM5 is described in Lohmann et al. (2007) and Lohmann and Hoose (2009). The microphysics scheme includes all phase changes between the water components (condensation, evaporation, freezing, melting, deposition, and sublimation) and precipitation processes (autoconversion of cloud droplets, accretion of raindrops with cloud droplets and snow flakes with cloud droplets and ice crystals, aggregation of ice crystals). Moreover, evaporation of raindrops and melting and sublimation of snowflakes are considered, as well as sedimentation of cloud ice. The cloud microphysics scheme is coupled to the aerosol scheme HAM through the processes of cloud droplet activation and ice crystal nucleation (Lohmann et al., 2007) as well as through in-cloud and below-cloud scavenging (Croft et al., 2009; Croft et al., 2010). Convective clouds are not radiatively active and have much simpler conversion rates (Tiedtke, 1989). The detrained condensate from convective clouds is a source for the stratiform cloud scheme.

Heterogeneous freezing in mixed-phase clouds occurs by contact and immersion freezing as discussed below. In the standard configuration, cirrus clouds are assumed to form by homogeneous freezing of supercooled solution droplets (Lohmann and Kärcher, 2002). Homogeneous and heterogeneous nucleation strongly depends on the vertical velocity that results in supersaturation. The vertical velocity is a superposition of the grid-scale vertical velocity and a sub-gridscale component, which is linked to the turbulent kinetic energy (Lohmann and Kärcher, 2002).
Since the ECHAM-HAM model validation in Lohmann and Hoose (2009), the cloud microphysics scheme has undergone the following scientific improvements.

1. While in the previous ECHAM6-HAM version cloud droplet activation followed the empirical scheme by Lin and Leaitch (1997), it now uses a parameterization of cloud droplet activation based on Köhler theory by Abdul-Razzak and Ghan (2000) as discussed in Stier (2016).

2. Previously, the increase in cloud droplet number concentration (CDNC) from cloud droplets that were detrained from convective clouds, was applied everywhere in the grid box. We now weight the detrained CDNC by the detrained mass and add it to the mass-weighted CDNC of the stratiform part. In addition, the split of the detrained cloud water mass into liquid water and ice was made consistent between the number concentrations and mass mixing ratios of cloud droplets and ice crystals.

3. We now assume the shape of ice crystals to be hexagonal plates of crystal type P1a following Pruppacher and Klett (1997). Before we used the empirical mass-size relationships from their Table 2.4, which are only valid for crystals between 0.3 and $1.5 \mathrm{~mm}$ in size. We replaced that with their empirical relationship in Table 2.2, which is valid from $10 \mu \mathrm{m}$ to $3 \mathrm{~mm}$ and thus covers the whole ice crystal size range. Also, while we assumed that all ice crystals are hexagonal plates in the cloud microphysics scheme, cirrus crystals were treated as spheres for the calculation of the effective ice crystal radius and ice cloud optical properties in Zhang et al. (2012). This inconsistency has been eliminated and ice crystals are now hexagonal plates everywhere in the module.

4. The heterogeneous nucleation scheme in the mixedphase cloud regime among temperatures between 273.15 and $238.15 \mathrm{~K}$ considers contact nucleation by mineral dust and immersion nucleation by black carbon and mineral dust following Lohmann and Hoose (2009). However, because there is no evidence that Aitken mode particles contribute to freezing (Marcolli et al., 2007), we now limit the immersion freezing of black carbon to particles in the accumulation mode or larger.

5. The temperature dependence of sticking efficiency used for accretion of ice crystals by snow has been changed to the expression used in Seifert and Beheng (2006).

6. In previous versions, the minimum $\mathrm{CDNC}$ (CDNCmin) was set to $40 \mathrm{~cm}^{-3}$. The justification for this choice was twofold: first, while observations of clouds with a lower CDNC exist (e.g, Terai et al., 2014; Wood et al., 2018), these smaller concentrations normally occur in clouds or pockets in clouds that are much smaller than our 
grid boxes. Second, so far we do not account for nitrate aerosols and our treatment of secondary organic aerosols is rather simplistic and likely underestimates the organic aerosol concentration (Zhang et al., 2012). Therefore we are likely to underestimate $\mathrm{CDNC}$, which we partly buffer by using $\mathrm{CDNCmin}=40 \mathrm{~cm}^{-3}$. However, CDNCmin has a large impact on the aerosol radiative forcing (Hoose et al., 2009). Therefore we introduced the option to have two ECHAM6.3-HAM2.3 versions, one that keeps the CDNCmin at $40 \mathrm{~cm}^{-3}$ and one in which we lower CDNCmin to $10 \mathrm{~cm}^{-3}$.

In addition to the scientific improvements, we removed smaller inconsistencies, such that cloud droplets and ice crystals could both grow and evaporate/sublimate in one time step and that there is nonzero CDNC below $238.15 \mathrm{~K}$, nonzero ice crystal number concentrations above $273.15 \mathrm{~K}$, and inconsistencies in the calculation of cloud cover, condensation, and the ice crystal number concentration in cirrus clouds. Moreover, the two-moment cloud microphysics scheme is now energy conserving and has been modularized.

\section{Model set-up and experiments}

In this paper, we compare results from the release version of ECHAM6-HAM2 with CDNCmin $=40 \mathrm{~cm}^{-3}$ (simulation REF) and the sensitivity simulations discussed below with observations. To address the impact of SLF on ECS in ECHAM6-HAM2, we conducted one simulation with no supercooled liquid water below $0{ }^{\circ} \mathrm{C}$ (simulation ALL_ICE) and one simulation with no ice formation at temperatures $>-35^{\circ} \mathrm{C}$ (simulation ALL_LIQ), similar to what has been done in Tan et al. (2016) and Lohmann (2002). The simulation ALL_ICE is set up such that all cloud droplets that are advected to colder temperatures are forced to freeze instantaneously and all the detrained cloud condensate is in the form of ice at temperatures $<0{ }^{\circ} \mathrm{C}$. The simulation ALL_LIQ is set up such that heterogeneous freezing is turned off in the temperature range between 0 and $-35^{\circ} \mathrm{C}$ and detrainment of ice crystals from convective clouds is restricted to temperatures below $-35^{\circ} \mathrm{C}$. Ice crystals sedimenting from colder into warmer cloud layers melt at $-35^{\circ} \mathrm{C}$. The number of cloud droplets which freeze at temperatures below $-35^{\circ} \mathrm{C}$ had to be reduced by a factor of 100 in order to keep the ice crystal number concentration realistic in simulation ALL_LIQ and to reduce tuning to a minimum.

In this paper we go beyond the study by Tan et al. (2016) and also test the impact of other aspects of clouds on ECS, such as the type of nucleation in cirrus. There are discussions if cirrus clouds are mainly formed by homogeneous nucleation as we assume in our reference simulation or are nucleated heterogeneously (Cziczo et al., 2013; Spichtinger and Krämer, 2012; Kärcher, 2017). We investigate the impact of homogeneous vs. heterogeneous freezing in cirrus clouds by performing one simulation in which all cirrus clouds form heterogeneously (simulation HET) instead of homogeneous nucleation in simulation REF. Heterogeneously nucleated cirrus clouds are optically thinner (Lohmann, 2008). Thus, with this simulation we aim to address the impact of cirrus on ECS that so far remains uncertain (Boucher et al., 2013).

Last but not least we investigate the impact of parameterized convection on ECS by performing a simulation in which we completely switched off convection (simulation NOCONV) as in Webb et al. (2015). This is normally performed only in simulations run at horizontal resolutions of less than $10 \mathrm{~km}$, at which the vertical motions associated with deep convection start to be resolved. While our horizontal resolution is much coarser and thus a convective parameterization is needed, there are some inconsistencies in terms of microphysics between convective and stratiform clouds. Therefore we evaluate how the cloud fields, the climate in general, and ECS are simulated if only large-scale clouds are allowed to form.

All simulations were performed in T63 spectral resolution, which corresponds to $1.875^{\circ} \times 1.875^{\circ}$ and 31 vertical layers with a top at $10 \mathrm{hPa}$. The present-day atmosphere-only simulations were run over 25 years, after a 3-month spin-up with fixed sea surface temperatures (SSTs) and sea-ice cover (averaged over the atmosphere model intercomparison project (AMIP) climatology for the years 2000-2015). To calculate ECS, ECHAM6-HAM2 has been coupled to a MLO of $50 \mathrm{~m}$ depth. The deep ocean heat flux is computed from the atmosphere-only simulations. Because the deep ocean heat flux adjusts to the different set-ups, we computed it individually for each of the five different set-ups used in this study. These simulations were spun up for 25 years after which the simulations were in equilibrium. We then ran them for another 25 years, over which the results were averaged.

The sensitivity studies conducted for our studies are summarized in Table 1. For the calculation of ECS, all simulations need to be in radiative equilibrium at the TOA. This might require retuning. To keep the different simulations as comparable as possible, we only adjusted two parameters inside the two-moment cloud microphysics scheme. $\gamma_{\mathrm{r}}$ speeds up the autoconversion rate of cloud droplets to grow to raindrops by collision-coalescence and accounts for the missing sub-grid-scale variability in cloud water and CDNC (Wood, 2002). $\gamma_{\mathrm{s}}$ is the corresponding process in the ice phase, which enhances the aggregation of ice crystals to form snow flakes (Lohmann and Ferrachat, 2010). The values of these two parameters are also included in Table 1 . In addition to the changes in the tuning parameters, we needed to decrease the time step from 7.5 to $5 \mathrm{~min}$ in simulation NOCONV because of numerical stability.

All of the simulations listed in Table 1 were run in three different set-ups: (i) atmosphere-only simulations with prescribed SST and sea ice cover using the AMIP 2000-2015 climatology with present-day aerosol emissions and greenhouse gas concentrations for comparison with observations, (ii) atmosphere-MLO simulations at $1 \times \mathrm{CO}_{2}$ concentrations 
Table 1. Set-up of the simulations together with the two tuning parameters that differ among the simulations.

\begin{tabular}{llrr}
\hline Simulation & Description & $\gamma_{\mathrm{r}}$ & $\gamma_{\mathrm{s}}$ \\
\hline REF & $\begin{array}{l}\text { Reference simulation with ECHAM6.3-HAM2.3 with CDNCmin }=40 \mathrm{~cm}^{-3} \\
\text { and only homogeneous freezing in cirrus clouds }\end{array}$ & 10.6 & 900 \\
& As REF, but without any supercooled liquid water at temperatures $<0{ }^{\circ} \mathrm{C}$ & 4 & 900 \\
ALL_ICE & As REF, but with only supercooled liquid water at temperatures $>-35^{\circ} \mathrm{C}$ & 25 & 900 \\
ALL_LIQ & As REF, but with only heterogeneous freezing in cirrus clouds & 14 & 300 \\
HET & As REF, but without any parameterization of convection & 175 & 900 \\
NOCONV & A & & \\
\hline
\end{tabular}

with preindustrial aerosol emissions and preindustrial levels of the other greenhouse gas, and (iii) atmosphere-MLO simulations at $2 \times \mathrm{CO}_{2}$ concentrations, keeping everything else as in (ii). For simulations (iii) the $\mathrm{CO}_{2}$ concentration was doubled before the 25-year spin-up period.

\section{Comparison of ECHAM6-HAM2 with observations}

An overview of the annual, global mean state of the climate in the different simulations is given in Table 2 together with observations, where available. The observations of global liquid water path (LWP) range between 30 and $90 \mathrm{~g} \mathrm{~m}^{-2}$ (Stubenrauch et al., 2013; Platnick et al., 2015, 2017; Stengel et al., 2017a; Poulsen et al., 2017). Elsaesser et al. (2018) restricted the LWP retrievals to ocean regions $\left(\mathrm{LWP}_{\mathrm{oc}}\right)$ and estimated $\mathrm{LWP}_{\mathrm{Oc}}$ from a combination of the SSM/I, TMI, AMSR-E, WindSat, SSMIS, AMSR-2, and GMI satellite data (MAC-LWP) as $81.4 \mathrm{~g} \mathrm{~m}^{-2}$. Limiting the other retrievals to ocean regions yields a global $\mathrm{LWP}_{\mathrm{oc}}$ of $42.9 \mathrm{~g} \mathrm{~m}^{-2}$ from MODIS (Platnick et al., 2015, 2017), $43.9 \mathrm{~g} \mathrm{~m}^{-2}$ from ATSR-2-AATSR (Stengel et al., 2017a; Poulsen et al., 2017), and $41 \mathrm{~g} \mathrm{~m}^{-2}$ from AVHRR-PM (Stengel et al., 2017b), illustrating the huge uncertainty of estimating $\mathrm{LWP}_{\mathrm{oc}}$. All simulations except for ALL_LIQ fall within this range. In simulation ALL_LIQ, $\mathrm{LWP}_{\mathrm{oc}}$ amounts to $110 \mathrm{~g} \mathrm{~m}^{-2}$ because no ice is formed at temperatures $>-35^{\circ} \mathrm{C}$.

The annual zonal mean LWP and ice water path (IWP) from all simulations as well as from satellite observations of LWP from multiple satellite sensors (Elsaesser et al., 2018), the MODIS satellite (Platnick et al., 2015, 2017), and the ATSR-2-AATSR satellites (Stengel et al., 2017a; Poulsen et al., 2017) and IWP from CALIPSO/CloudSat (Li et al., 2012) are shown in Fig. 1. Because the MAC-LWP observations are only available over oceans, we limit the comparison of LWP to ocean regions. Both retrievals from visiblenear-infrared sensors and microwave sensors have biases in retrieving LWP (Seethala and Horvath, 2010; Lebsock and $\mathrm{Su}, 2014)$. Lebsock and $\mathrm{Su}$ (2014) mentioned four biases in LWP retrievals for MODIS (visible-near-infrared sensor) and AMSR-E (microwave sensor): a bias at large solar zenith angles (MODIS), missing pixels of low-lying clouds that are not detected (MODIS), LWP retrievals in cloud-free scenes (AMSR-E), and the partitioning of the microwave signal between cloud and precipitation signals (AMSR-E). The LWP bias of microwave-sensor-based products in clearsky scenes has been recently corrected by Elsaesser et al. (2018). The LWP estimates of microwave retrieval products are most reliable in regions where LWP is much larger than the rainwater path (RWP). Thus, Elsaesser et al. (2018) recommend restricting the LWP satellite data to regions in which LWP/(LWP + RWP) $>0.8$. This $\mathrm{LWP}_{\text {oc,low_pr }}$ covers areas dominated by stratocumulus, trade wind cumulus regions in the subtropics, the Southern Ocean, high latitudes in the Northern Hemisphere, and parts of the north Atlantic and north Pacific. LWP $_{\text {oc,low_pr }}$ from MAC-LWP should thus have the smallest retrieval biases. Therefore we use it to evaluate the model LWP as shown in Fig. 1.

The new multi-satellite observations of $\mathrm{LWP}_{\mathrm{oc}}$ by Elsaesser et al. (2018), averaged over the years 1988-2016, show a maximum LWP in the tropics and, on average, their estimate is twice as high as the retrievals from MODIS and ATSR-2-AATSR both for the years 2003-2012. LWP $_{\text {oc }}$ from MODIS and ATSR-2-AATSR, conversely, increases towards the poles and only a weak secondary maximum is indicated near the Equator. All observations show high values of $\mathrm{LWP}_{\mathrm{Oc}}$ in the storm tracks in both hemispheres, but the exact location varies among the different observations. The most noticeable difference between $\mathrm{LWP}_{\mathrm{oc}}$ and $\mathrm{LWP}_{\mathrm{oc}, \text { low_pr }}$ is the absence of data in the intertropical convergence zone (ITCZ). In fact, the agreement of simulations REF and HET in terms of the zonal mean structure of $\mathrm{LWP}_{\mathrm{oc}, \text { low_pr with }}$ observations is very good everywhere and better than with $\mathrm{LWP}_{\mathrm{oc}}$. $\mathrm{LWP}_{\mathrm{oc}, \text { low_pr }}$ is too low at high latitudes in simulation ALL_ICE and the maxima in the extratropics are over-

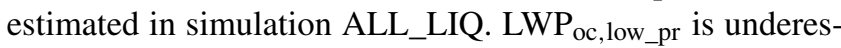
timated everywhere in simulation NOCONV because of the large speedup of the autoconversion rate required to reach radiative equilibrium at the TOA in this set-up.

The cloud-top CDNC for oceanic clouds $\left(N_{1, \text { oc,top }}\right)$ with temperatures between 268 and $300 \mathrm{~K}$ has been obtained from satellite data (Bennartz and Rausch, 2017) for the years 2003-2015. From the model simulations, oceanic cloud-top CDNCs were used for temperatures $>273.2 \mathrm{~K}$. $N_{1, \text { oc, top }}$ is less zonally symmetric than LWP as a result of the higher emissions in the Northern Hemisphere. $N_{1, \text { oc, top }}$ reaches values of $>100 \mathrm{~cm}^{-3}$ between 30 and $60^{\circ} \mathrm{N}$ in the observations 
Table 2. Global annual mean of oceanic $\mathrm{LWP}_{\mathrm{oc}} ; \mathrm{LWP}_{\mathrm{oc}, \text { low_pr }}$; IWP; vertically integrated global cloud droplet $\left(N_{1}\right)$; CDNC at cloud top over oceans $\left(N_{1, \text { oc,top }}\right)$; ice crystal number concentration $\left(N_{\mathrm{i}}\right)$; total cloud cover $(\mathrm{CC})$; precipitation rate $(P)$; shortwave $(\mathrm{SW})$, longwave (LW), and net cloud radiative effect (CRE) from observations; and 20-year atmosphere-only present-day model simulations with prescribed

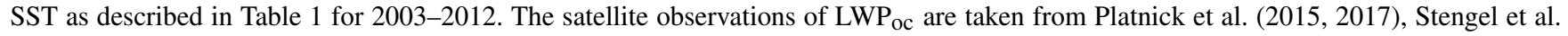

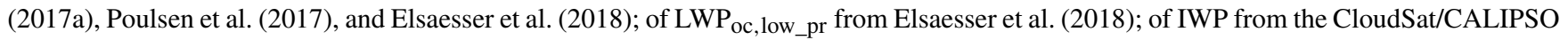

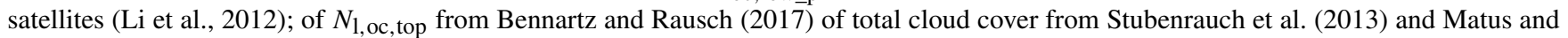
L'Ecuyer (2017); of precipitation rate from the GPCP version 2.3 data set (Adler et al., 2003, 2012). The CRE satellite data are averaged over the period 2001-2011 from the Clouds and the Earth's Radiant Energy System Energy Balanced and Filled Ed2.6r data set (Boucher et al., 2013) and are described in Loeb et al. (2009, 2018). For the uncertainty range of the SW CRE data from CloudSat and CALIPSO are also considered (Matus and L'Ecuyer, 2017) and for LW CRE data from the TOVS satellite are also considered (Susskind et al., 1997). See legend of Fig. 1 for details of the observations.

\begin{tabular}{|c|c|c|c|c|c|c|}
\hline & OBS & REF & ALL_ICE & ALL_LIQ & HET & NOCONV \\
\hline $\mathrm{LWP}_{\mathrm{oc}}, \mathrm{g} \mathrm{m}^{-2}$ & $81.4(30-90)$ & 70.6 & 75.9 & 111.3 & 62.5 & 53.3 \\
\hline $\mathrm{LWP}_{\mathrm{oc}, \mathrm{low}_{-} \mathrm{pr}}, \mathrm{g} \mathrm{m}^{-2}$ & $73.5 \pm 5.5$ & 76.2 & 70.4 & 141.1 & 68.1 & 42.0 \\
\hline IWP, $\mathrm{g} \mathrm{m}^{-\overline{2}^{\mathrm{r}}}$ & $25 \pm 7$ & 14.8 & 16.5 & 8.6 & 26 & 11.7 \\
\hline$N_{1}, 10^{10} \mathrm{~m}^{-2}$ & - & 3.1 & 2.4 & 6.4 & 2.9 & 4.5 \\
\hline$N_{1, \text { oc }, \text { top }}, \mathrm{cm}^{-3}$ & $72 \pm 38$ & 78.3 & 95.6 & 69.6 & 77.4 & 74.2 \\
\hline$N_{\mathrm{i}}, 10^{8} \mathrm{~m}^{-2}$ & - & 7.9 & 8.4 & 9.3 & 10.7 & 5.8 \\
\hline $\mathrm{CC}, \%$ & $68 \pm 5$ & 68.1 & 67.8 & 70.6 & 66.3 & 71.2 \\
\hline$P, \mathrm{~mm} \mathrm{~d}^{-1}$ & $2.7 \pm 0.2$ & 2.99 & 2.92 & 2.87 & 3.03 & 3.00 \\
\hline SW CRE, $\mathrm{W} \mathrm{m}^{-2}$ & $-47.3(-44$ to -53.3$)$ & -49.9 & -48.2 & -62.6 & -49.9 & -52.2 \\
\hline LW CRE, $\mathrm{W} \mathrm{m}^{-2}$ & $26.2(22$ to 30.5$)$ & 24.1 & 22.4 & 35.6 & 24.6 & 24.7 \\
\hline Net CRE, $\mathrm{W} \mathrm{m}^{-2}$ & $-21.1(-17.1$ to -22.8$)$ & -25.8 & -25.8 & -26.9 & -25.4 & -27.5 \\
\hline
\end{tabular}

(Fig. 1). All model simulations fail to produce such high values north of $40^{\circ} \mathrm{N}$, probably because of an insufficient transport of aerosol particles to the Arctic (Bourgeois and Bey, 2011), missing nitrate aerosols, and underestimation of particulate organic aerosols (Zhang et al., 2012), all of which contribute to underestimating the concentration of cloud condensation nuclei. $N_{1, o c, t o p}$ is well simulated south of $30^{\circ} \mathrm{N}$, especially in simulation ALL_LIQ. $N_{1, \text { oc,top }}$ is highest in simulation ALL_ICE (Table 2) and overestimated with respect to the observations. This is caused by the lower speedup of the autoconversion rate in simulation ALL_ICE (Table 1), which reduces the sink of cloud droplets in this simulation and causes higher CDNC at all altitudes compared to simulation REF (not shown).

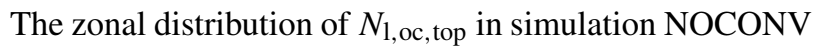
differs from the other simulations. It peaks near the Equator because the clouds here cannot form by convection and instead the stratiform cloud scheme needs to take over. As the rain formation depends on CDNC only in the stratiform cloud microphysics scheme but not in the convective one, warm rain is less efficiently formed in the tropics in the stratiform scheme, causing a buildup of cloud droplets in simulation NOCONV as portrayed in Fig. 1. The CDNC peak in the tropics in simulation NOCONV deviates strongly from observations, as do the lower-than-observed values in the extratropics.

ECHAM6-HAM2 in general has problems simulating IWP values in the observed range. This deficiency can largely be attributed to an underestimation in the ice crystal size in simulation REF at least for clouds with a COD $<3$ (Gasparini et al., 2018). The only simulation in which IWP in the global mean agrees with the observations is simulation HET (Table 2) because the heterogeneous nucleation is limited by the number concentration of dust aerosols. The dust number concentration is smaller than the number concentration of soluble aerosols that can freeze homogeneously and freezing commences at a lower relative humidity and a higher temperature in simulation HET. Because of the limited number concentration of dust aerosols and the faster depositional growth at higher temperatures, the heterogeneously nucleated ice crystals are larger than the ones nucleated homogeneously. Because of this, they sediment and aggregate more rapidly, causing simulation HET to be initially out of radiative balance. Here retuning was necessary to slow down the rate of aggregation and at the same time speed up the rate of autoconversion. This resulted in one of the lowest LWPs of all simulations and the highest IWPs with the highest ice crystal number concentration.

The IWP peak in the tropics in Fig. 1 is related to liquidorigin cirrus clouds (Wernli et al., 2016; Kraemer et al., 2016; Gasparini et al., 2018) forming the anvils from deep convection in the ITCZ as well as in the warm conveyor belt in the storm tracks. The peak in the ITCZ is not captured in any of the model simulations, suggesting that the model severely underestimates the detrained cloud ice in deep convective clouds. Cloud ice in the extratropics is underestimated in all simulations but simulations HET and ALL_ICE. IWP is largest in simulation HET due to retuning as discussed above. 

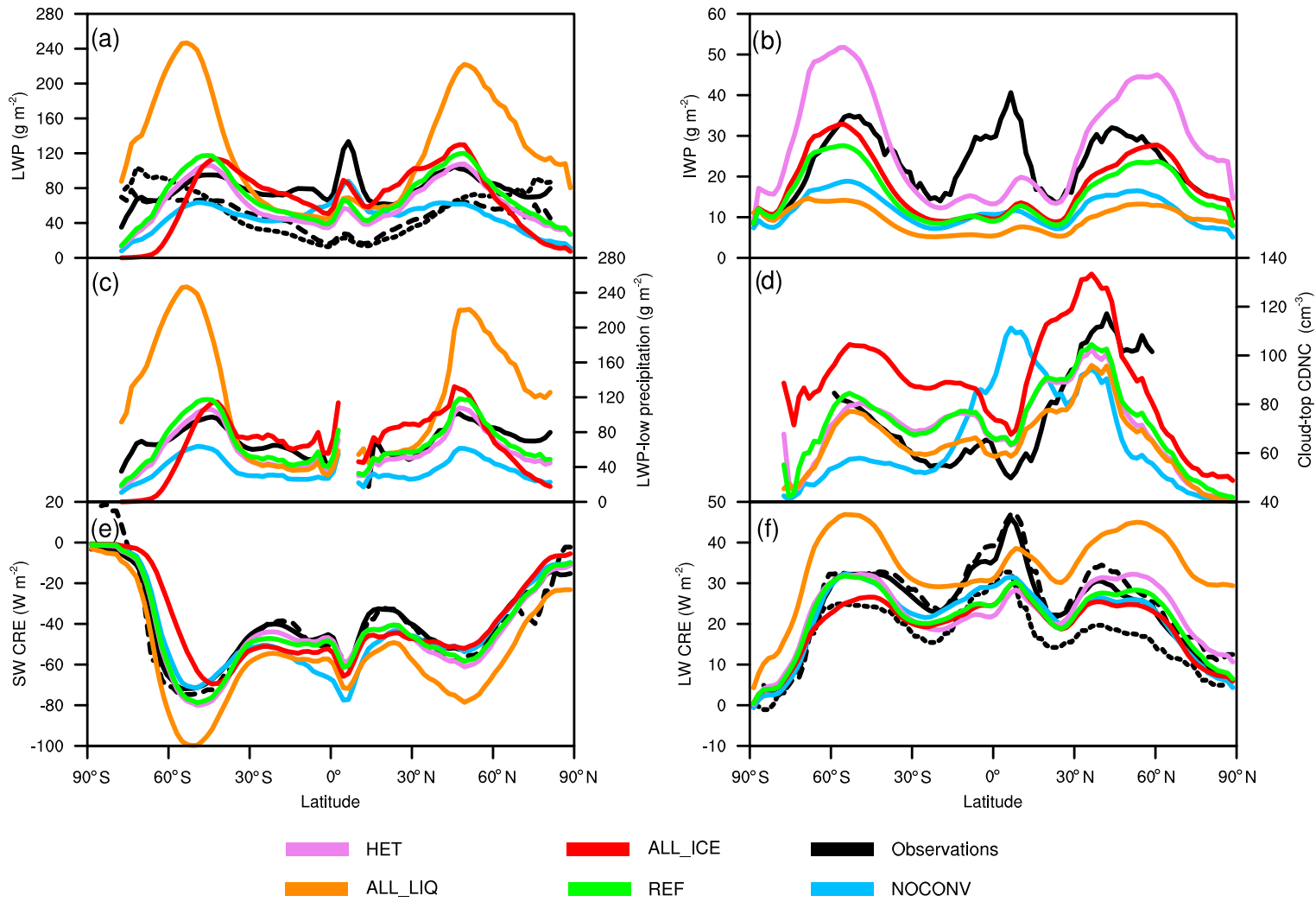

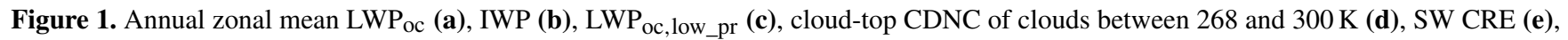
and LW CRE (f) from the atmosphere-only present-day simulations for the years 2003-2012 as described in Table 1 and observations of LWP from multiple satellite sensors for the years 1988-2016 by Elsaesser et al. (2018) (solid line), from MODIS-AQUA collection 6.1 for the years 2003-2012 (Platnick et al., 2015, 2017) (dotted line), from ATSR-2-AATSR for the years 2003-2012 (Stengel et al., 2017a) (dashed line), CloudSat + CALIPSO satellite observations of IWP for the years 2006-2010 from Li et al. (2012), low-precipitating oceanic LWP from Elsaesser et al. (2018) for the years 2003-2012, oceanic cloud-top CDNC for the years 2003-2015 from Bennartz and Rausch (2017), SW and LW CRE. The solid SW and LW CRE lines are from CERES 2003-2012 (Loeb et al., 2009, 2018), the dashed ones from ERBE for the years 1985-1989, and the dotted ones for LW CRE from TOVS satellite data for the years 1985-1993 (Susskind et al., 1997).

Its zonal distribution shows that the underestimation of IWP in the tropics is compensated for by an overestimation in the extratropics. Simulation ALL_ICE best matches the magnitude of IWP in the extratropics but shifts the peaks slightly polewards of the observations.

The total cloud cover in ECHAM6-HAM2 is that of largescale clouds because convective clouds are considered to be short lived and to decay within one model time step except for the detrained condensate in the anvils that is taken as a source for the stratiform cloud scheme. The global mean total cloud cover does not vary much among the different simulations and it falls within the observed range of $68 \pm 5 \%$ (Stubenrauch et al., 2013) in all simulations. It is secondlargest in simulation ALL_LIQ because of its large LWP. It is highest in simulation NOCONV because here all clouds are large scale and contribute to the cloud cover.

The observed precipitation rate from GPCP of $2.7 \mathrm{~mm} \mathrm{~d}^{-1}$ (Adler et al., 2003) averaged over 1981-2010 is overestimated by $6-13 \%$ in all simulations, a feature that ECHAM6-
HAM2 shares with its host model ECHAM6 (Stevens et al., 2013). As discussed in Stevens et al. (2013), GPCP seems to underreport precipitation, and higher precipitation rates are more consistent with the best observational estimates of the surface energy budget (Stephens et al., 2012).

The cloud radiative effect (CRE) is the difference between the all-sky radiation at the TOA and the clear-sky radiation. The shortwave (SW) CRE amounts to $-47.3 \mathrm{~W} \mathrm{~m}^{-2}$ with a range from -46 to $-53.3 \mathrm{~W} \mathrm{~m}^{-2}$ in the satellite data (Loeb et al., 2009, 2018; Zelinka et al., 2017). In all simulations, except ALL_LIQ, SW CRE amounts to about $-50 \mathrm{~W} \mathrm{~m}^{-2}$, which lies within the observed range. SW CRE is most negative and outside the observational range in simulation ALL_LIQ because of its high LWP and total cloud cover (see also Fig. 1). Conversely, it is least negative in simulation ALL_ICE, in which LWP is rather small and hence $\tau$ is smallest. Here SW CRE is severely underestimated south of $40^{\circ} \mathrm{S}$ due to the lack of supercooled liquid water. While too much absorption of shortwave radiation over the South- 
ern Ocean has been a problem in the many GCMs because of insufficient supercooled liquid water (e.g., Williams et al., 2013; Bodas-Salcedo et al., 2014; Kay et al., 2016), in our model this problem only arises in the extreme simulation ALL ICE.

LW CRE amounts to $26.2 \mathrm{~W} \mathrm{~m}^{-2}$ with a range from 22 to $30.5 \mathrm{~W} \mathrm{~m}^{-2}$ in the satellite data (Loeb et al., 2009, 2018; Susskind et al., 1997; Zelinka et al., 2017). As for SW CRE, all simulations but ALL_LIQ calculate LW CRE to be about $24-25 \mathrm{~W} \mathrm{~m}^{-2}$ in good agreement with observations. Again LW CRE is smallest in simulation ALL_ICE and highest and outside the observational range in simulation ALL_LIQ (see also Fig. 1). Due to the severe underestimation of cloud ice in the tropics in all simulations, LW CRE is systematically underestimated in the tropics. The exception is simulation ALL_LIQ in which the underestimation in tropical cloud ice is compensated for by the thickest high level clouds (Fig. 2).

The global mean observed net CRE ranges between -17.1 and $-22.8 \mathrm{~W} \mathrm{~m}^{-2}$. Here all simulations are more negative than observed, i.e., they overestimate the net negative radiative effect of clouds.

The vertical distribution of the globally and annually averaged cloud liquid water and cloud ice is shown in Fig. 2. Cloud liquid water has its maximum at around $800 \mathrm{hPa}$ associated with low clouds where it varies between 20 and $30 \mathrm{mg} \mathrm{kg}^{-1}$ in the different simulations. It is lowest in simulation NOCONV because of the drastically enhanced autoconversion rate (Table 1). Cloud liquid water decreases to zero at around $400 \mathrm{hPa}$ except in simulation ALL_LIQ in which ice formation is limited to temperatures $<-35^{\circ} \mathrm{C}$. Unfortunately no observational data of the vertical distribution of cloud liquid water are available.

The vertical distribution of cloud ice has been derived from CALIPSO/CloudSat (Li et al., 2012). It peaks at $400 \mathrm{hPa}$ with $6 \mathrm{mg} \mathrm{kg}^{-1}$ and becomes negligible at altitudes above $100 \mathrm{hPa}$ and below $900 \mathrm{hPa}$ (Fig. 2). Here the differences among the sensitivity experiments are more pronounced. In simulations REF and NOCONV the shape of the distribution looks similar to the observed distribution, but the peak value is underestimated by $30-50 \%$ and in simulation REF a secondary maximum is present at around $780 \mathrm{hPa}$. This peak is related to cloud ice over the Southern Ocean and Antarctica (not shown). In simulation ALL_LIQ, in which the global annual mean IWP is smallest due to suppressed ice formation in mixed-phase clouds, cloud ice peaks at $250 \mathrm{hPa}$ and drops to zero at $600 \mathrm{hPa}$. This simulation differs most from the observations. It also has the lowest cloud cover in the lower troposphere and the highest cloud fraction between 200 and $400 \mathrm{hPa}$ (Fig. 2). Conversely, simulation NOCONV has the highest coverage of low-level clouds and the smallest coverage of cirrus clouds.

In simulation ALL_ICE the comparison of cloud ice with observations is also less favorable compared to simulation REF because more cloud ice than observed is simulated in the lower atmosphere while the underestimation of cloud ice at higher altitudes has not noticeably improved. The overall best agreement with observations is seen in simulation HET. This is the only simulation in which the global annual mean IWP lies within the observational uncertainty (Table 2). However, the peak in cloud ice at $400 \mathrm{hPa}$ is $25 \%$ too large and too narrow. Although the freezing mechanism was only changed for cirrus clouds, the overall higher amount of cloud ice extends to lower altitudes, causing an overestimation in cloud ice between 600 and $900 \mathrm{hPa}$. This is mainly a result of the reduced speedup of the aggregation rate that also affects cloud ice in mixed-phase clouds.

SLF has been obtained from the CALIOP satellite and has been compared to an earlier version of ECHAM6-HAM2 (Komurcu et al., 2014). At that time ECHAM6-HAM2 seriously underestimated SLF. This can partly be explained by differences in the definition of SLF in the satellite data and in the model. In addition, some of the model improvements mentioned above were added after the study by Komurcu et al. (2014). As the lidar signal becomes attenuated at $\mathrm{COD}>3$, the CALIOP satellite data are only representative for all cloud tops not overlaid by clouds with COD $>3$. SLF of the model data is diagnosed similarly to CALIOP starting from the highest cloud layers as long as the cumulative COD of these cloud layers is less than or equal to 3. As shown in Fig. 3, ECHAM6-HAM2 still underestimates SLF but on average simulates SLFs twice as high as presented in Komurcu et al. (2014). At $-10{ }^{\circ} \mathrm{C}$ SLF amounts to $63 \%$ in CALIOP but only $37 \%$ in simulation REF. The difference between the observed and simulated SLF decreases at colder temperatures because of the general decrease in SLF with decreasing temperature.

SLF from all ECHAM simulations is significantly underestimated except for simulations ALL_LIQ and NOCONV. Simulation NOCONV actually matches the observed SLF rather well, mainly because supercooled liquid water exists at higher altitudes than in simulation REF (Fig. 2). This points to a potential deficiency as to how we handle detrainment from convective clouds or convection itself. In simulation REF we assume that if we are in the Wegener-BergeronFindeisen (WBF) regime, following the definition of Korolev (2007) as described in Lohmann and Hoose (2009), and cloud ice is already present, the detrained condensate will be in the form of ice. It is only detrained as supercooled liquid water if the vertical velocity is sufficiently high to exceed saturation with respect to liquid water. This assumption seems to cause a too efficient WBF process, thus depleting the supercooled liquid water too rapidly. We will rethink our approach in the future.

The control simulation in CESM from Tan et al. (2016) simulates a SLF of only $20 \%$ at $-10^{\circ} \mathrm{C}$. Based on their hypothesis that an underestimation in SLF translates into an underestimation in ECS, a smaller underestimation of SLF in simulation REF should lead to a smaller underestimation of ECS in ECHAM6-HAM2. Based on the simulated SLFs, we expect ECS to be lowest in simulation ALL_ICE and to suc- 
(a) Cloud water $\left(\mathrm{mg} \mathrm{kg}^{-1}\right)$

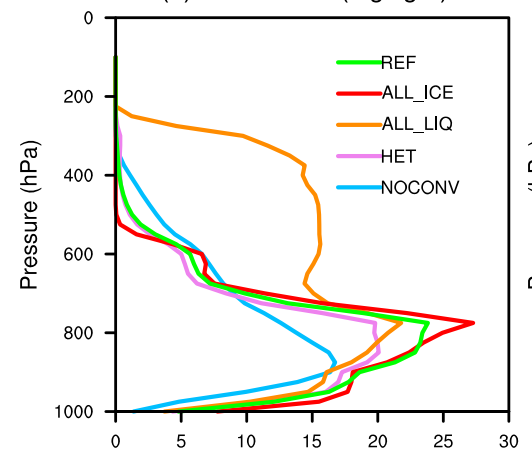

(b) Cloud ice $\left(\mathrm{mg} \mathrm{kg}^{-1}\right)$

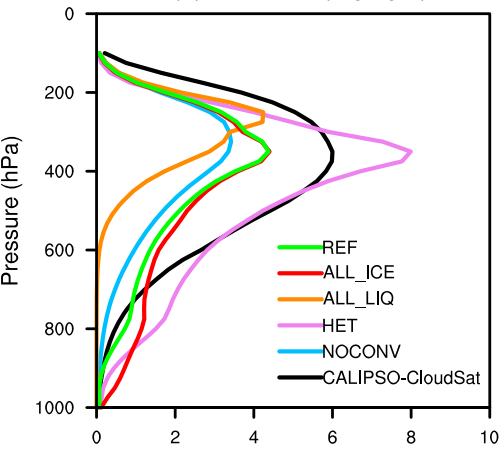

(c) Cloud fraction (\%)

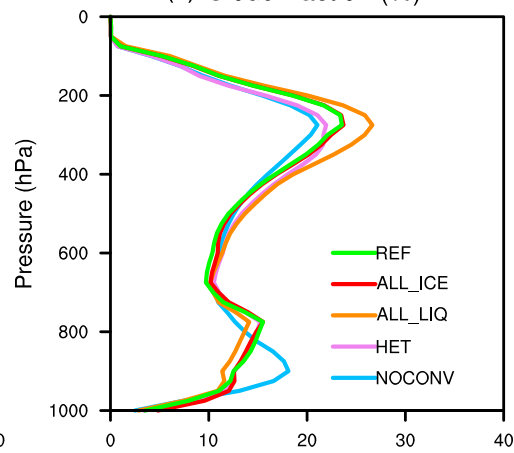

Figure 2. Annual global mean cloud liquid water content (a), ice water content (b) in milligrams per kilogram, and cloud cover (c) in percent as a function of pressure in hectopascals from the various sensitivity atmosphere-only present-day simulations for the years 2003-2012 described in Table 1 and observations of the ice water content from CALIPSO-CloudSat for the years 2006-2010 by Li et al. (2012).

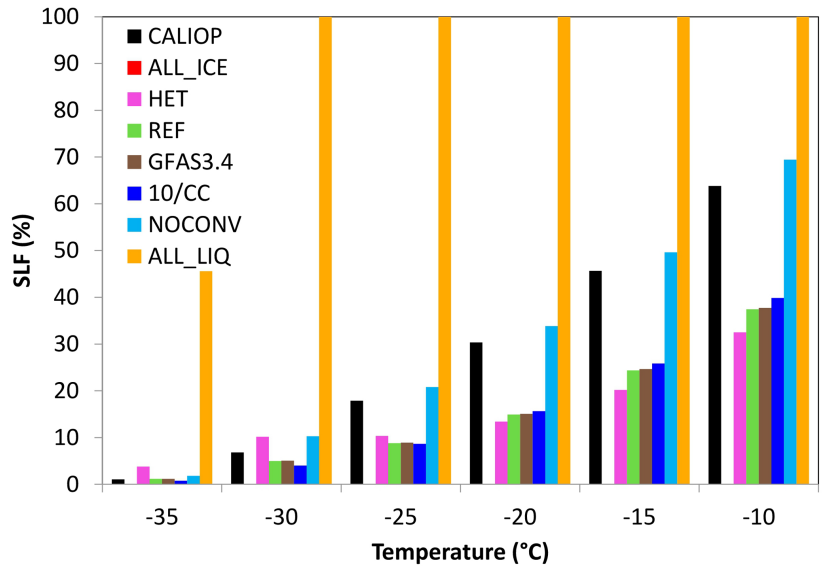

Figure 3. Frequency of occurrence of SLF in percent for clouds with $\mathrm{COD}<3$ in different temperature bins from CALIOP observations for the years 2006-2010 and the various sensitivity simulations from the atmosphere-only present-day simulations for the years 2003-2012 described in Table 1.

cessively increase in simulations HET, REF, NOCONV, and ALL_LIQ.

\section{Equilibrium climate sensitivity}

In a warmer climate, the saturation-specific humidity increases by $7 \%{ }^{\circ} \mathrm{C}^{-1}$ of temperature increase according to the Clausius-Clapeyron equation. Because the relative humidity has been found to remain rather constant (Soden et al., 2002), this causes an increase in the specific humidity and speeds up the hydrological cycle leading to higher liquid water contents in clouds and higher precipitation rates.

ECS from all our sensitivity simulations is shown in Table 3. It ranges between 1.8 and $2.6 \mathrm{~K}$ and with that lies on the lower side of the range of ECS estimated in the last IPCC re- port (Collins et al., 2013; Flato et al., 2013) and from CMIP5 models (Forster et al., 2013). Similar to Tan et al. (2016), ECS increases by $\sim 30 \%$ when increasing SLF from almost zero to one (simulations ALL_ICE and ALL_LIQ in this paper vs. Low-SLF and High-SLF in Tan et al., 2016). Contrary to their large increase in ECS from their reference simulation to simulation High-SLF, ECS does not change among simulations REF, NOCONV, and ALL_LIQ but remains at 2.5$2.6 \mathrm{~K}$ despite the increase in SLF at $-10^{\circ} \mathrm{C}$ from $\sim 30 \%$ in HET and $\sim 40 \%$ in REF to $\sim 70 \%$ in NOCONV and $100 \%$ in ALL_LIQ, i.e., only ECS in simulation ALL_ICE is noticeably different. This suggests that ECHAM6-HAM2 is more sensitive at low SLF. These results seem to support the hypothesis that an increase in ECS is only sensitive to SLF if too little shortwave radiation is reflected back to space from mixed-phase midlatitude clouds, i.e., when they are composed of ice instead of liquid water. This has also been suggested by Frey and Kay (2017), who modified CAM5 to detrain more liquid water at colder temperatures in shallow convective clouds, which occur in the cold sector of midlatitude cyclones, for example. It is important that these mixed-phase clouds are not shielded by ice clouds in order for a change in their cloud phase to affect ECS (Bodas-Salcedo, 2018). Since in ECHAM6-HAM2 this shortwave bias is most pronounced in simulation ALL_ICE, this is the only simulation with a distinctively lower ECS. In the reference version of CAM5, too much shortwave radiation is absorbed over the Southern Ocean in their present-day climate (Kay et al., 2016), which explains why ECS is also sensitive to an increase in SLF in this model (Tan et al., 2016). In addition, Tan et al. (2016) did not use a MLO, but a fully coupled dynamic ocean, which could impact the comparison with our results because different methods can lead to differing ECS estimates (Frey et al., 2017).

In order to prove our hypothesis for the different relationship between SLF and ECS in ECHAM6-HAM2, we evaluate the changes in cloud fraction as a function of cloud-top 
Table 3. Global annual mean changes of surface temperature $\left(\Delta T_{\mathrm{S}}\right)$, liquid water path $(\Delta \mathrm{LWP})$, ice water path $(\Delta \mathrm{IWP})$, vertically integrated cloud droplet $\left(\Delta N_{1}\right)$ and ice crystal number concentration $\left(\Delta N_{\mathrm{i}}\right)$, total cloud cover $(\Delta \mathrm{CC}), \mathrm{SW}$ CRE $(\Delta \mathrm{SW}$ CRE), LW CRE $(\Delta \mathrm{LW} \mathrm{CRE})$, and net CRE from the radiative kernel (RK) method and as normally diagnosed in equilibrium after a $\mathrm{CO}_{2}$ doubling averaged over the years 26 to 50 of the coupled atmosphere - MLO model simulations as well as the net clear-sky feedback parameter $\lambda^{\mathrm{cs}}$ diagnosed according to Block and Mauritsen (2013). The individual simulations are described in Table 1. Different from Table 2, here the changes in LWP are global and not limited to ocean regions.

\begin{tabular}{|c|c|c|c|c|c|}
\hline & REF & ALL_ICE & ALL_LIQ & HET & NOCONV \\
\hline$\Delta T, \mathrm{~K}$ & 2.5 & 1.83 & 2.51 & 2.58 & 2.56 \\
\hline$\Delta \mathrm{LWP}, \mathrm{g} \mathrm{m}^{-2}$ & 2.54 & 4.75 & 0.80 & 3.18 & 0.72 \\
\hline$\Delta \mathrm{IWP}, \mathrm{g} \mathrm{m}^{-2}$ & -0.40 & -0.40 & -0.54 & -1.06 & -0.31 \\
\hline$\Delta \mathrm{CC}, \%$ & -1.43 & -0.82 & -1.13 & -1.23 & -1.15 \\
\hline$\Delta \mathrm{SW}$ CRE (RK), $\mathrm{W} \mathrm{m}^{-2}$ & 1.13 & -0.51 & 1.00 & 0.87 & 1.69 \\
\hline$\Delta \mathrm{LW}$ CRE $(\mathrm{RK}), \mathrm{W} \mathrm{m}^{-2}$ & -0.34 & -0.20 & 0.46 & -0.17 & -0.35 \\
\hline$\Delta$ net $\mathrm{CRE}(\mathrm{RK}), \mathrm{W} \mathrm{m}^{-2}$ & 0.78 & -0.71 & 1.45 & 0.69 & 1.34 \\
\hline$\Delta \mathrm{SW} C R E, \mathrm{~W} \mathrm{~m}^{-2}$ & 1.03 & -0.11 & 0.78 & 0.65 & 1.51 \\
\hline$\Delta \mathrm{LW}$ CRE, $\mathrm{W} \mathrm{m}^{-2}$ & -1.58 & -1.30 & -1.22 & -1.45 & -1.49 \\
\hline$\Delta$ net $\mathrm{CRE}, \mathrm{W} \mathrm{m}^{-2}$ & -0.54 & -1.42 & -0.44 & -0.80 & 0.03 \\
\hline$\lambda^{\mathrm{cs}}, \mathrm{W} \mathrm{m}^{-2} \mathrm{~K}^{-1}$ & -1.38 & -1.42 & -1.50 & -1.26 & -1.45 \\
\hline
\end{tabular}

pressure and $\mathrm{COD}$ between the $2 \times \mathrm{CO}_{2}$ and $1 \times \mathrm{CO}_{2}$ climates. Because mixed-phase clouds are more prevalent in midlatitudes and high latitudes than in the tropics and subtropics (Matus and L'Ecuyer, 2017), we expected the largest differences there. The histograms in Figs. 4 and 5 are taken polewards of $40^{\circ}$ latitude in both hemispheres. They are taken from a satellite perspective, by using the COSP-ISCCP simulator (Bodas-Salcedo et al., 2011). This means that the cloud-top pressure refers to the highest cloud in each single sub-column used by the simulator. Sub-columns are used in the simulator to account for sub-grid-scale variability in the cloud (top) distribution. From Fig. 4 we see that only in simulation ALL_ICE is there a large abundance of low- and mid-level optically thin extratropical clouds (with $\tau<1.3$ ) in the present climate. These clouds show a marked decrease accompanied with a marked increase in medium optical depth clouds $(3.6<\tau<60)$ between 560 and $800 \mathrm{hPa}$ in the $2 \times \mathrm{CO}_{2}$ climate (Fig. 5). These clouds and their changes are absent in all other simulations with a higher SLF (REF, HET, NOCONV, and ALL_LIQ). Only in simulation ALL_ICE are these optically thin ice clouds not shielded by higher clouds prevalent in the present-day climate (not shown) and are converted to low- and mid-level liquid water clouds of medium optical depth in the $2 \times \mathrm{CO}_{2}$ climate.

To estimate the radiative effect of this increase in COD, we calculate the different components of the global cloud feedback parameter $\lambda_{\mathrm{c}}$ using the radiative kernel decomposition method described in Zelinka et al. (2012a, b). This method decomposes $\lambda_{\mathrm{c}}$ into feedbacks that are associated with changes in cloud amount $\lambda_{\text {amt }}$, cloud-top pressure $\lambda_{\text {ctp }}$, and COD $\lambda_{\tau}$ as shown in Fig. 6 for all simulations. $\lambda_{\text {ctp }}$ is positive because of the shift of clouds to higher altitudes in the warmer climate (see also Fig. 7) that enhances their LW CRE. At the same time, the total cloud amount decreases in a warmer climate, most noticeable at lower altitudes (Fig. 7). This decrease in low/mid-level clouds reduces the negative net CRE and also constitutes a positive feedback. $\lambda_{\tau}$ is negative in most simulations and smaller than other cloud feedbacks so that $\lambda_{\mathrm{c}}$ is positive in most simulations. $\lambda_{\mathrm{c}}$ is negative $\left(-0.4 \mathrm{~W} \mathrm{~m}^{-2} \mathrm{~K}^{-1}\right)$ only in simulation ALL_ICE because of its large negative $\lambda_{\tau}$. In all other simulations $\lambda_{\mathrm{c}}$ ranges between $0.3 \mathrm{~W} \mathrm{~m}^{-2} \mathrm{~K}^{-1}$ and $0.6 \mathrm{~W} \mathrm{~m}^{-2} \mathrm{~K}^{-1}$. The value of $0.6 \mathrm{~W} \mathrm{~m}^{-2} \mathrm{~K}^{-1}$ corresponds to the mean of the analyzed GCMs in AR5 (Boucher et al., 2013). The estimates from the other simulations (except ALL_ICE) fall within the $90 \%$ range of the cloud feedback of -0.2 to $0.6 \mathrm{~W} \mathrm{~m}^{-2} \mathrm{~K}^{-1}$ as assessed in AR5 (Boucher et al., 2013).

The largest differences among the simulations are associated with changes in $\lambda_{\tau}$, which varies between $-0.6 \mathrm{~W} \mathrm{~m}^{-2} \mathrm{~K}^{-1}$ in simulation ALL_ICE and $0.1 \mathrm{~W} \mathrm{~m}^{-2} \mathrm{~K}^{-1}$ in simulation NOCONV. In simulation ALL_ICE, the large negative value of $\lambda_{\tau}$ can be explained with the largest increase in the LWP of $4.8 \mathrm{~g} \mathrm{~m}^{-2}$ (Table 3) due to the phase change from cloud ice to cloud liquid water mainly in low- and mid-level midlatitude clouds (Fig. 5). This causes a negative optical depth feedback in all regions, but most pronounced polewards of $40^{\circ}$ (Fig. 8). Note that simulation ALL_ICE is the only simulation in which the overall cloud feedback parameter is dominated by changes in COD. The results of simulation ALL_ICE agree qualitatively with the results from Bodas-Salcedo (2018) for regions with large-scale subsidence in which optically thin ice clouds in the present-day climate are not shielded by higher clouds and hence for which the COD feedback is most important. In all other simulations, the cloud feedback is dominated by changes in cloud amount and cloud-top pressure (Fig. 6). 

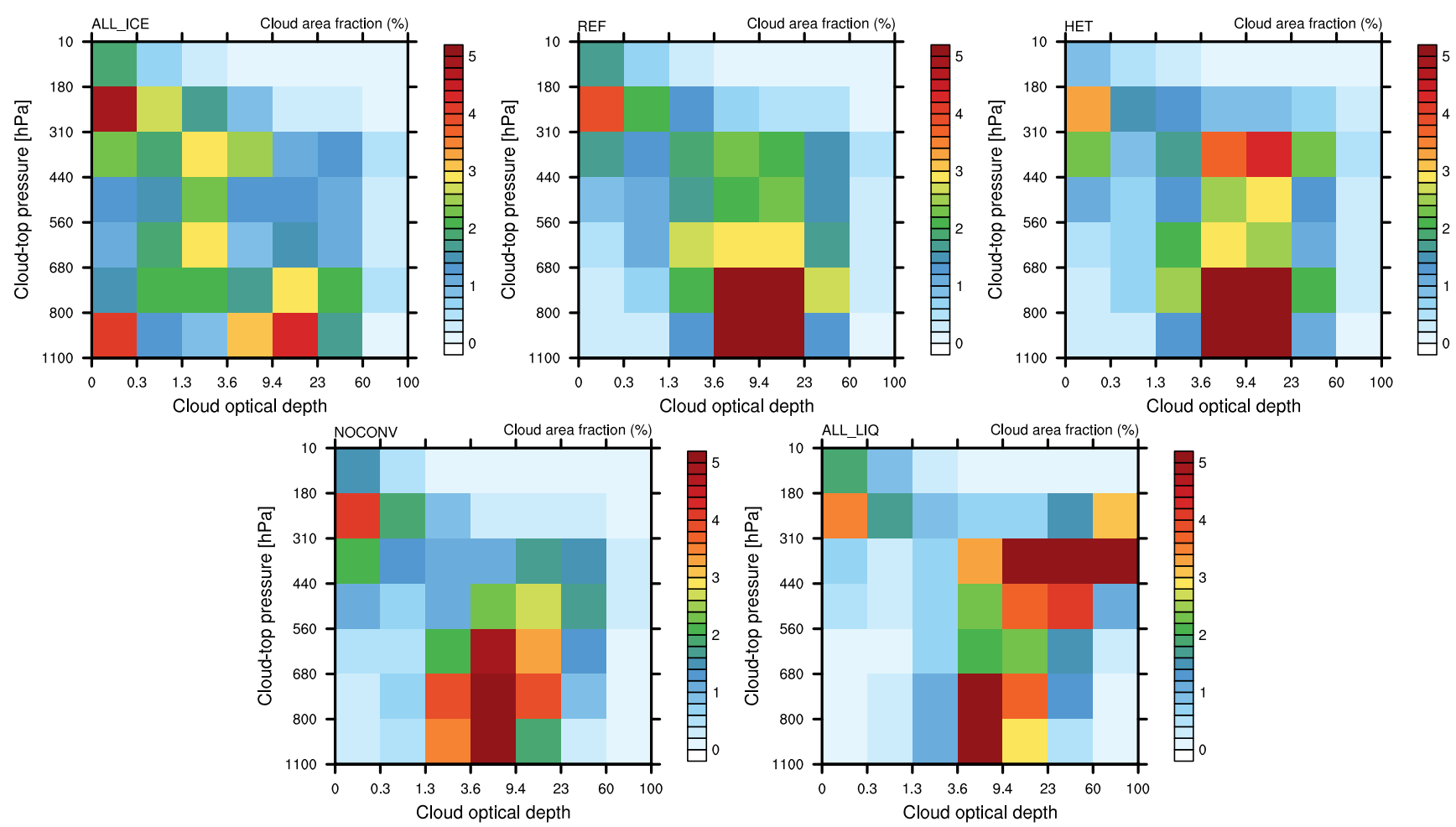

Figure 4. Distribution of cloud fraction in the extratropics $\left(>40^{\circ} \mathrm{S}\right.$ and $\left.\mathrm{N}\right)$ as a function of cloud optical depth and cloud-top pressure between the $2 \times \mathrm{CO}_{2}$ and the $1 \times \mathrm{CO}_{2}$ climate in simulations ALL_ICE, HET, REF, NOCONV, and ALL_LIQ from the last 25 years of the MLO simulations described in Table 1.

In the other simulations, shown in Fig. 5 for midlatitudes and high latitudes, a rather different picture emerges. Here $\tau$ of low clouds hardly changes or decreases as the majority of them are already composed of cloud droplets in the present climate and only a small phase change from ice to liquid occurs due to the doubling of $\mathrm{CO}_{2}$. In all simulations, except for simulation NOCONV, a negative cloud-phase feedback is also visible in the tropics. This negative feedback arises because some tropical clouds that glaciate at the tops, either due to the presence of ice-nucleating particles in the mixed-phase temperature regime or because their tops extend to altitudes with temperatures $<-35^{\circ} \mathrm{C}$ in the present climate, will remain supercooled in the warmer climate and hence become optically thicker (Figs. 8 and 9).

In the warmer climate, the static stability increases in areas with marine stratus, stratocumulus, and trade wind cumuli in all simulations. This is accompanied by a stronger moisture gradient, which promotes stronger drying by more entrainment (Gettelman and Sherwood, 2016), which in turn causes the marine subtropical clouds to become thinner and their optical depth to decrease. In most simulations this leads to a positive COD feedback in the subtropics as shown in Fig. 8.

The parameterization of convective clouds in ECHAM6HAM2 assumes that they form and dissipate in one time step. During their lifetime, they can detrain cloud water and ice in the environment. Thus the negative COD feedback in the tropics and midlatitudes indicates that more cloud condensate is detrained in the form of liquid or supercooled liquid water rather than as cloud ice in the warmer climate. Thus, next to the rise of the melting level in the warmer climate, the rise of the homogeneous freezing level is also important for the negative cloud-phase feedback. This is best seen in simulation ALL_LIQ in which no ice exists at mixed-phase temperatures, yet the negative cloud-phase feedback still operates in the tropics (Figs. 8 and 9). In the global mean, this negative cloud-phase feedback is visible in all our simulations as a simultaneous increase in cloud liquid water and decrease in cloud ice in the warmer climate at a given pressure level (Fig. 7). In midlatitudes and the tropics it shows up as an increase in optically thicker clouds and decrease in optically thinner clouds for the same cloud-top pressure (Figs. 5 and 9).

The second most important contributor to the differences in the overall cloud feedback between simulations ALL_ICE and ALL_LIQ is the change in cloud-top pressure $\left(\lambda_{\text {ctp }}\right)$. $\lambda_{\text {ctp }}$ varies between $0.1 \mathrm{~W} \mathrm{~m}^{-2} \mathrm{~K}^{-1}$ in simulation ALL_ICE and $0.4 \mathrm{~W} \mathrm{~m}^{-2} \mathrm{~K}^{-1}$ in simulation ALL_LIQ. The cloud-top pressure feedback is mainly related to cirrus clouds and has been estimated from satellite observations to amount to $0.2 \mathrm{~W} \mathrm{~m}^{-2} \mathrm{~K}^{-1}$ (Zhou et al., 2014). We obtain a cloud-top 

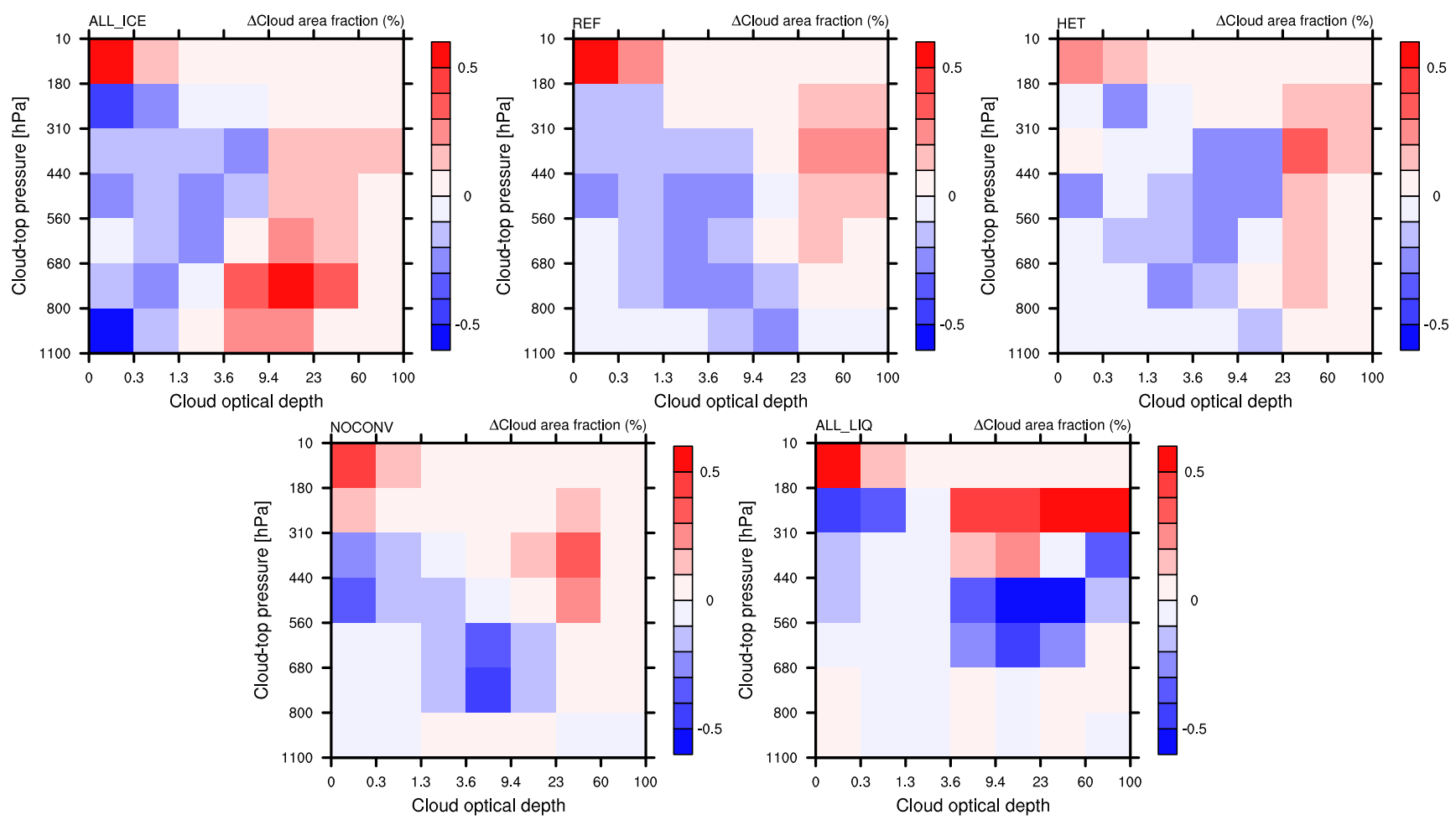

Figure 5. Changes in the distribution of cloud fraction in the extratropics ( $>40^{\circ} \mathrm{S}$ and $\mathrm{N}$ ) as a function of cloud optical depth and cloud-top pressure between the $2 \times \mathrm{CO}_{2}$ and the $1 \times \mathrm{CO}_{2}$ climates in simulations ALL_ICE, HET, REF, NOCONV, and ALL_LIQ from the last 25 years of the MLO simulations described in Table 1.

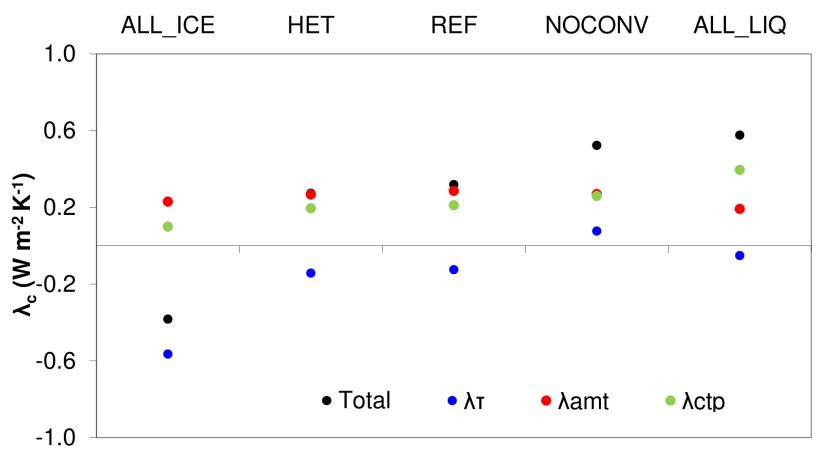

Figure 6. Components of the globally averaged cloud feedback parameter $\lambda_{\mathrm{c}}$ in $\mathrm{W} \mathrm{m}^{-2} \mathrm{~K}^{-1}$ for the simulations described in Table 1 . $\lambda_{\tau}$ accounts for changes in cloud optical depth, $\lambda_{\mathrm{amt}}$ accounts for changes in cloud amount, and $\lambda_{\text {ctp }}$ accounts for changes in cloudtop pressure.

pressure feedback of about this value in all other simulations. We also computed the cloud feedbacks separately for low and non-low clouds following the decomposition by Zelinka et al. (2016), which leads to a weaker cloud-top pressure feedback but in general qualitatively similar results for all simulations (not shown). $\lambda_{\text {ctp }}$ is largest in simulation ALL_LIQ in which the global mean changes in cloud liquid water and cloud ice are distinctively different from all other simulations (Fig. 7). It is the only simulation in which cloud liquid water decreases throughout the lower and mid-troposphere because here the poleward shift of the storm tracks and the upward shift of convective clouds are least compensated for by changes from cloud ice to cloud liquid water. The changes in simulation ALL_LIQ are accompanied with the largest decrease in cloud cover between 750 and $370 \mathrm{hPa}$. Cloud liquid water increases between 250 and $400 \mathrm{hPa}$ at the expense of cloud ice in simulation ALL_LIQ. In all other simulations, the concurrent increase in cloud liquid water and decrease in cloud ice occurs at altitudes below $400 \mathrm{hPa}$. The different vertical structure of cloud liquid water and cloud ice in simulation ALL_LIQ is a consequence of the design of this simulation. Because cloud ice only forms at temperatures below $-35^{\circ} \mathrm{C}$, cloud droplets are carried upwards to this temperature, such that the optically thick clouds extend to higher altitudes in the $2 \times \mathrm{CO}_{2}$ climate (see Figs. 5 and 9), causing the largest cloud-top pressure feedback as shown in Fig. 6 .

The opposite effect can be seen in simulation ALL_ICE, in which all cloud water is converted to ice already at $0{ }^{\circ} \mathrm{C}$. The increase in cloud liquid water in low and mid-level clouds in the warmer climate is largest in this simulation mainly because of the negative cloud-phase feedback (Fig. 7). This 

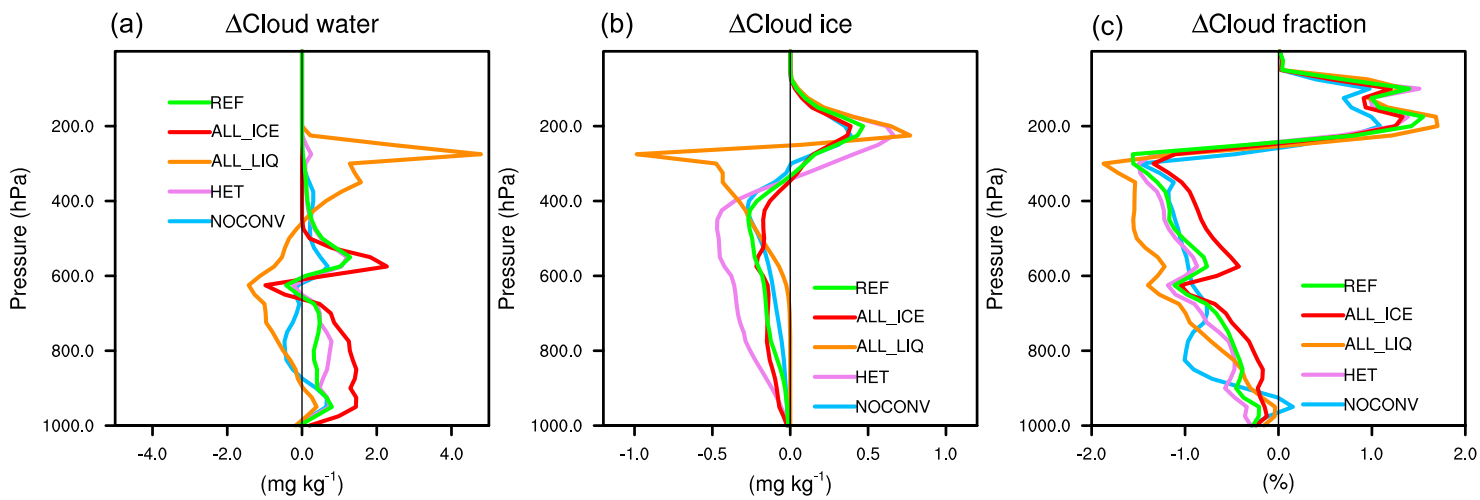

Figure 7. Change in the annual global mean cloud liquid water content (LWC, a) and ice water content (IWC, b) in milligrams per kilogram as a function of pressure in hectopascals between the $2 \times \mathrm{CO}_{2}$ and $1 \times \mathrm{CO}_{2}$ climates for the simulations described in Table 1 .
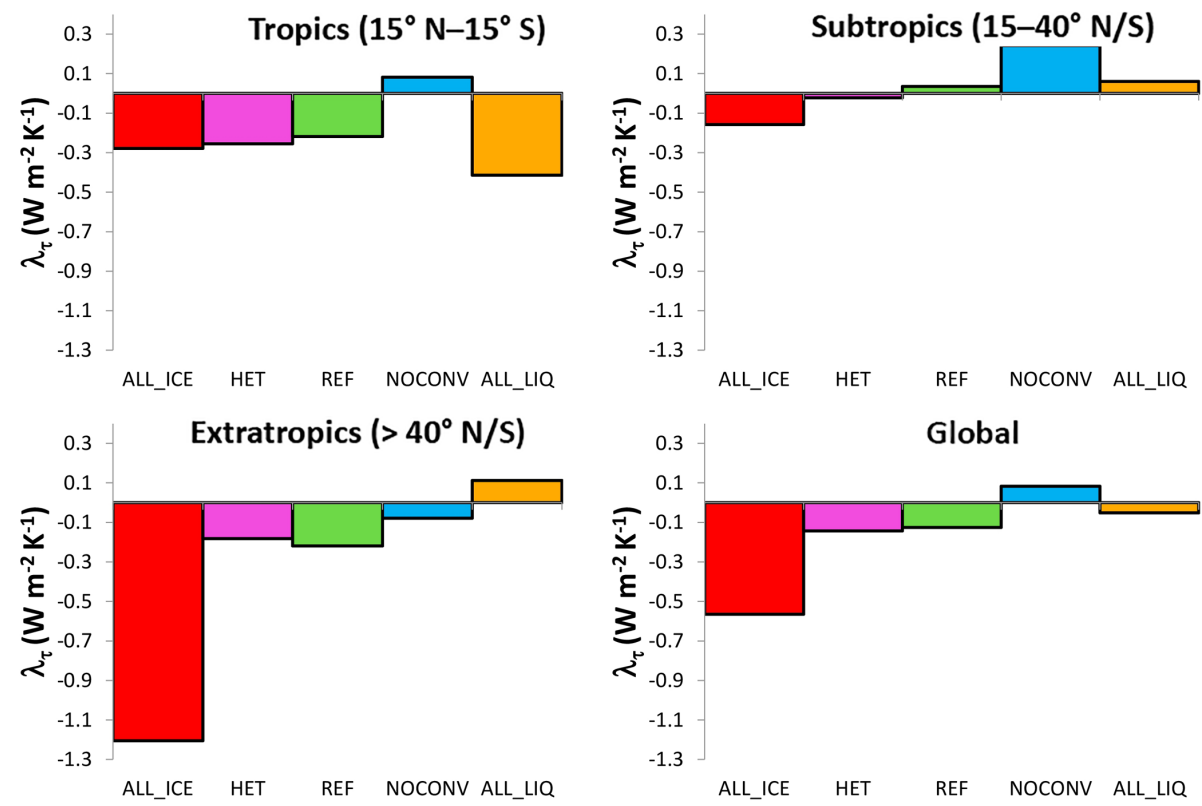

Figure 8. Tropical, subtropical, extratropical, and global cloud optical depth feedback parameter $\lambda_{\tau}$ in $\mathrm{W} \mathrm{m}^{-2} \mathrm{~K}^{-1}$ for the sensitivity simulations described in Table 1.

combined with only a modest increase in cloud ice and cloud cover between 250 and $100 \mathrm{hPa}$ (Fig. 7) causes the cloud-top pressure feedback to be smallest in this simulation (Fig. 6).

Simulation NOCONV is the only simulation in which $\lambda_{\tau}$ is slightly positive. $\lambda_{\tau}$ is negative in all other simulations in the tropics (Fig. 8) because more cloud condensate is detrained in the form of liquid or supercooled liquid water in the warmer climate. The absence of a convection parameterization and hence detrainment in simulation NOCONV on average leads to a positive tropical $\lambda_{\tau}$, i.e., the tropical and subtropical clouds in simulation NOCONV become optically thinner.

To summarize, the negative COD feedback only dominates the overall cloud feedback if the low- and mid-level midlatitude clouds consist of ice in the present climate and change to liquid in the $2 \times \mathrm{CO}_{2}$ climate as in simulation ALL_ICE. However, this does not imply that the overall cloud feedback remains more or less constant in the other simulations. In fact, $\lambda_{c}$ almost doubles from simulations REF and HET to simulations NOCONV and ALL_LIQ, caused by the large increase in cloud-top pressure feedback in simulation ALL_LIQ and a positive $\lambda_{\tau}$ in simulation NOCONV as explained above. This marked increase in the overall cloud feedback from simulations HET and REF to simulations NOCONV and ALL_LIQ is, however, not reflected in an increase in ECS because the net clear-sky feedback parameter, i.e., the sum of the clear-sky Planck, water vapor, lapse rate, and surface albedo feedbacks, is largest in simulation ALL_LIQ followed by simulation NOCONV (Table 3). 

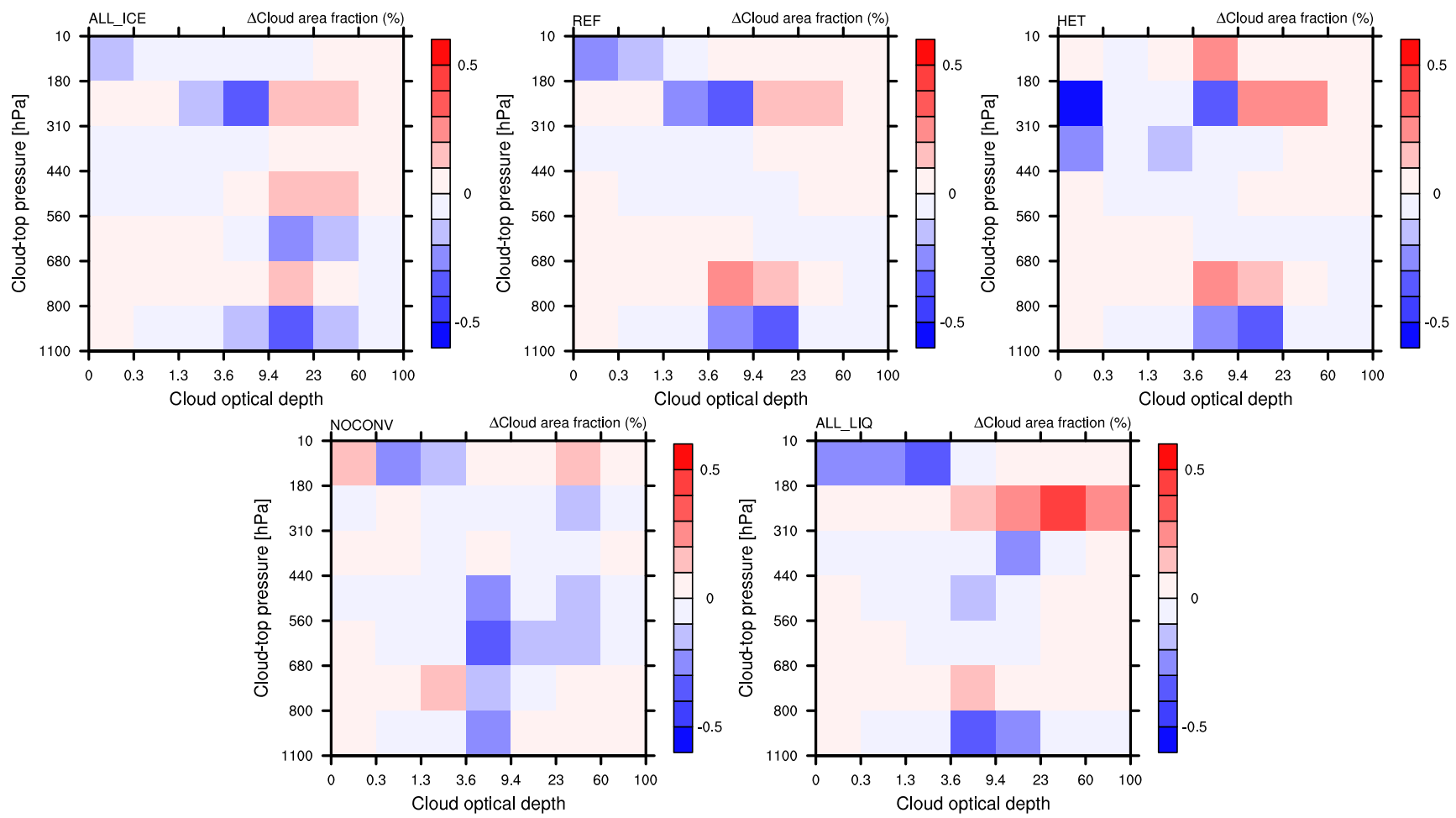

Figure 9. As Fig. 5 but for the tropics $\left(15^{\circ} \mathrm{S}-15^{\circ} \mathrm{N}\right)$.

We hypothesize that different processes contribute to the rather similar ECS in all simulations but ALL_ICE: in simulation ALL_LIQ, this seems to be caused by the optically thick clouds that tend to cluster in the tropics and become optically thicker there. This is apparent from Fig. 9, in which the upward shift in cirrus clouds with an increase in cirrus optical depth between 180 and $310 \mathrm{hPa}$ is much more pronounced in simulation ALL_LIQ than in simulation REF. In addition, the negative cloud-phase feedback is restricted to ice clouds that formed at altitudes with temperatures $<-35^{\circ} \mathrm{C}$ in the $1 \times \mathrm{CO}_{2}$ climate that are now liquid clouds (Fig. 7).

This increase in optical depth of high clouds causes their SW CRE to be more negative and completely offsets the reduction in LW CRE from the decrease in cloud cover in the tropics in simulation ALL_LIQ (Fig. 10). Such a clustering of convective clouds was found by Lohmann and Roeckner (1995) using the ECHAM4 model when the emissivity of cirrus clouds was set to 1 (black cirrus), i.e., when the infrared optical depth was increased. No convective clustering was seen in the reference simulation in which the cirrus emissivity was calculated as a function of ice water path and in a simulation with transparent cirrus in the infrared. In a warmer climate, convective clouds have been found to cluster further (Bony et al., 2016). The clustering of convective clouds in the warmer climate arises because cloud tops remain at nearly the same temperature in a warmer climate (e.g., Hartmann and Larson, 2002) but are in a more stable environment, which decreases anvil outflow in the upper troposphere and decreases the anvil cloud fraction (Bony et al., 2016). In ECHAM this decrease is most pronounced at altitudes below $250 \mathrm{hPa}$ (Fig. 7) from which more longwave radiation is emitted to space. This leads to an overall negative feedback (e.g., Hartmann and Larson, 2002; Mauritsen and Stevens, 2015) because of the much larger clear-sky area and offsets the positive cloud feedback. In the present-day climate of simulation ALL_LIQ, the least amount of outgoing longwave radiation is emitted to space because the clouds are optically thickest in this simulation. In a warmer climate, these clouds cluster further in the intertropical convergence zone as can be seen from the largest increase in LW CRE as diagnosed from the radiative kernel (RK) method (Fig. 10). Because these clouds are optically thick, this large increase in LW CRE (RK) is overcompensated for by a decrease in SW CRE (RK), causing the net CRE (RK) in the intertropical convergence zone to be as negative in simulation ALL_LIQ as in simulation REF.

The cloud-top pressure feedback in the extratropics that is significantly positive in all simulations but ALL_ICE where it is close to zero (not shown) is overcompensated for by decreases in cloud cover. As shown in Fig. 10, SW CRE and SW CRE (RK) become less negative in the extratropics and dominate over the decrease in LW CRE and LW CRE (RK), causing a positive $\triangle$ net CRE at midlatitudes. The generally 
(a) SW TOA clear-sky $\left(\mathrm{W} \mathrm{m}^{-2}\right)$

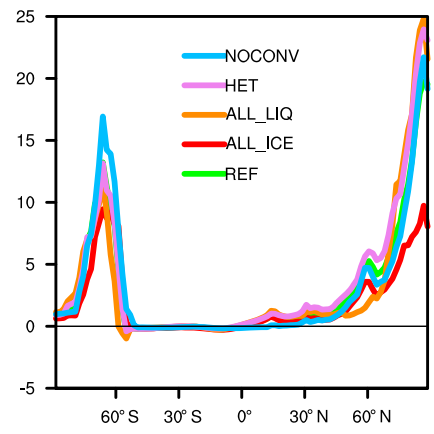

(b) SW CRE (RK) TOA $\left(\mathrm{W} \mathrm{m}^{-2}\right)$

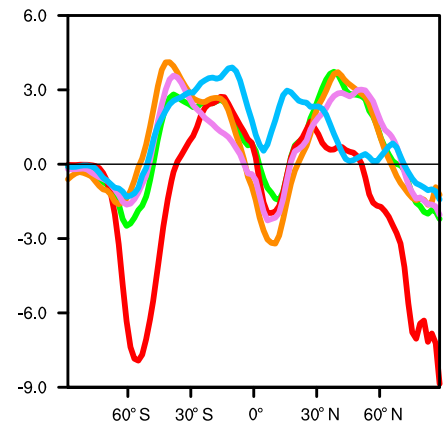

(c) SW CRE TOA $\left(\mathrm{W} \mathrm{m}^{-2}\right)$

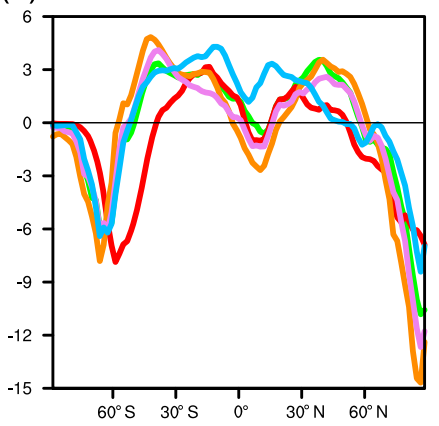

LW TOA clear-sky $\left(\mathrm{W} \mathrm{m}^{-2}\right)$

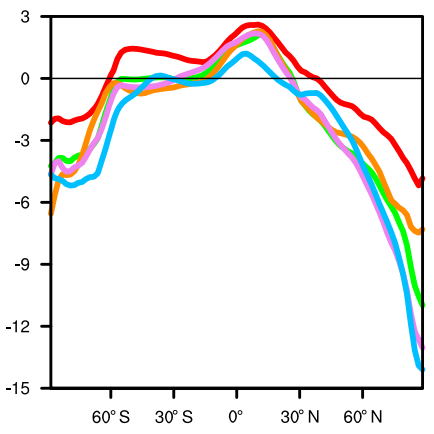

LW CRE (RK) TOA $\left(\mathrm{W} \mathrm{m}^{-2}\right)$

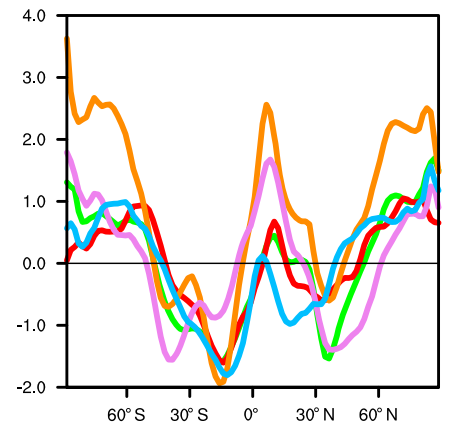

LW CRE TOA $\left(\mathrm{W} \mathrm{m}^{-2}\right)$

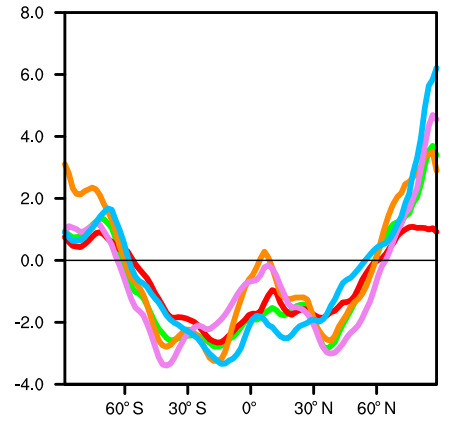

Surface temperature $(K)$

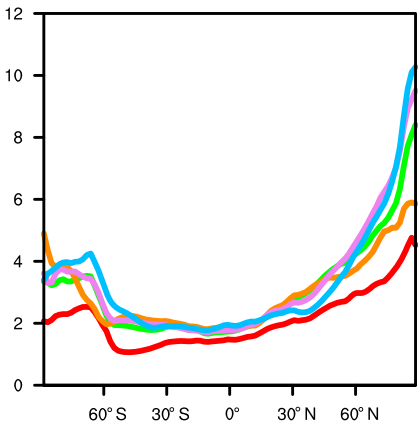

Net CRE (RK) TOA $\left(\mathrm{W} \mathrm{m}^{-2}\right)$

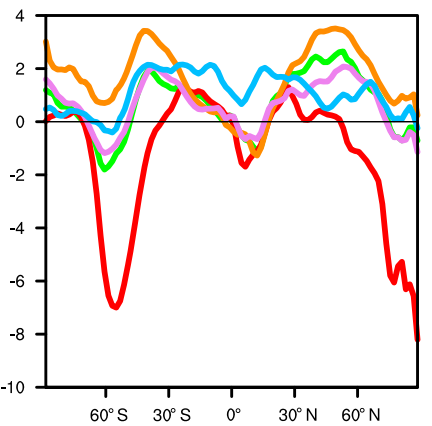

Net CRE TOA $\left(\mathrm{W} \mathrm{m}^{-2}\right)$

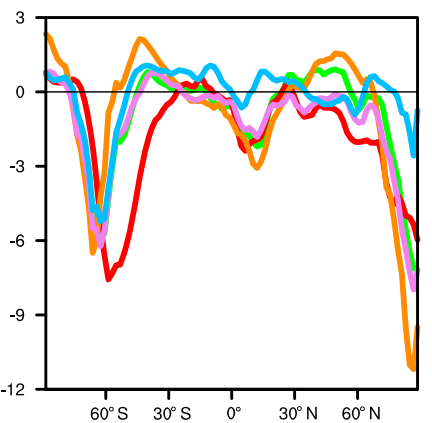

Figure 10. Changes in the annual zonal SW and LW net clear-sky radiation in watts per square meter at the top-of-the-atmosphere and surface temperature $(\mathrm{K})(\mathbf{a})$; changes in $\mathrm{SW}$, $\mathrm{LW}$, and net cloud radiative effects between the $2 \times \mathrm{CO}_{2}$ and $1 \times \mathrm{CO}_{2}$ climates calculated based on the radiative kernel method (b) and normally diagnosed (c) for the simulations described in Table 1. Negative values for the change in clear-sky outgoing longwave radiation denote higher values in the $2 \times \mathrm{CO}_{2}$ climate. Please note the different vertical axes.

smaller positive and larger negative changes in net CRE than in net CRE (RK) are caused by compensating changes in non-cloud climate components as described in detail in Shell et al. (2008). In high latitudes, the decrease in surface albedo due to melting of Arctic sea ice causes especially large negative $\triangle \mathrm{SW} C R E$ and $\triangle$ net $\mathrm{CRE}$ values polewards of $70^{\circ} \mathrm{N}$. In the clear-sky, water vapor and $\mathrm{CO}_{2}$ absorb more longwave radiation in the warmer climate than in the present day. This decreases the difference between all-sky and clear-sky fluxes and causes the LW CRE to be less positive. Differences in surface temperature operate in opposite ways. While more longwave radiation is emitted to space in the warmer climate (negative Planck feedback), more longwave radiation is also absorbed by clouds and re-emitted to the surface (positive cloud feedback). This clear-sky compensation in the longwave is most pronounced in simulation ALL_LIQ, which is the only simulation in which the global mean $\triangle \mathrm{LW} \mathrm{CRE}$ (RK) is positive (Table 3).

The changes between simulation REF and ALL_LIQ are qualitatively comparable to the ones from Lohmann and Roeckner (1995), for which the difference in climate sensitivity was also rather small between the reference simulation and the black cirrus simulation, both of which also had a positive cloud feedback and an increase in net CRE. There was a noticeable difference between the transparent cirrus and the reference simulation because only the transparent cirrus sim- 
ulation produced a negative cloud feedback and a decrease in net CRE. While in our simulation $\triangle \mathrm{CRE}$ is always negative or close to zero, it is most negative in simulation ALL_ICE, which corresponds to the transparent cirrus simulation.

ECS in simulation HET is also similar to simulation REF, but differences in $\triangle \mathrm{LW}$ CRE (RK) exist. As in simulation ALL_LIQ, in simulation HET the increase in $\triangle$ LW CRE (RK) in the tropics is also larger than in simulation REF (Fig. 10) because of the upward shift of ice clouds (Fig. 7) and their increase in optical depth (Fig. 9). Because these ice clouds are of medium optical depth, the large $\triangle \mathrm{LW}$ CRE (RK) is overcompensated for by a decrease in $\triangle \mathrm{SW}$ CRE (RK), causing $\Delta$ net CRE (RK) and $\triangle$ net CRE to be similar to in simulation REF (Table 3).

In simulation NOCONV the outgoing longwave clear-sky radiation is increased the most. While it is also slightly decreased in the tropics, the decrease is smallest in this simulation because of the absence of convection (Fig. 10). The associated absence of detrainment slows down the WegenerBergeron-Findeisen process on the one hand, but required the largest speedup of the autoconversion rate on the other hand (Table 1). The latter causes the present-day cloud liquid water and its increase in the warmer climate to be smallest (Tables 2 and 3). This explains the overall positive $\lambda_{\tau}$ and the second largest $\lambda_{\mathrm{c}}$. The most negative clear-sky LW radiation changes in NOCONV explain why ECS does not increase compared to in simulation REF. The absence of convection also seems to limit the increase in cirrus clouds (increase in cloud cover at altitudes above $250 \mathrm{hPa}$; Fig. 7).

\section{Conclusions}

In this study we used the newly developed ECHAM6.3HAM2.3 coupled global aerosol-climate model to assess the influence of different cloud processes for ECS. This work was motivated by the findings of Tan et al. (2016) using CAM5, who showed a large influence of correcting the underestimated SLF in present-day mixed-phase clouds on ECS. An underestimate of SLF has also been found in other models (Komurcu et al., 2014; Barrett et al., 2017a, b) and in a different version of CAM5 (Kay et al., 2016). The SLF was found to be most sensitive to the glaciation rate, which in turn is influenced by cloud ice microphysics and the model's vertical resolution (Barrett et al., 2017a, b). In ECHAM6-HAM2, SLF could be improved when switching off the convective parameterization entirely. The absence of convection and hence detrained cloud ice slows down the glaciation rate in ECHAM6-HAM2, which corroborates the findings by Barrett et al. (2017a) on the importance of the glaciation rate for SLF.

In ECHAM6-HAM2, ECS is much smaller than in the CAM5 GCM used by Tan et al. (2016). It varies between 1.8 and $2.5 \mathrm{~K}$ in ECHAM6-HAM2 versus between 3.9 and $5.7 \mathrm{~K}$ in CAM5 (Tan et al., 2016). Thus, while ECS is on the low side of the ECS range between 2.1 and $4.7 \mathrm{~K}$ in IPCC AR5 (Forster et al., 2013; Flato et al., 2013) in ECHAM6HAM2, it is on the high side in CAM5. Note that the percentage increase in ECS of $30 \%$ between the extreme scenarios (ALL_ICE to ALL_LIQ in ECHAM6-HAM2 vs. Low-SLF to High-SLF in CAM5) is similar, indicating that the relative contribution of the negative cloud-phase feedback to the overall ECS is comparable in both GCMs.

However, important differences between the two GCM studies are apparent: increasing SLF in ECHAM6-HAM2 from its calculated values in the reference simulation to one as in simulation ALL_LIQ does not increase ECS in contrast to the findings by Tan et al. (2016). Part of this difference could be caused by the overestimation of shortwave absorption over the Southern Ocean due to too efficient freezing in low- and mid-level shallow convective clouds in CAM5 (Kay et al., 2016). We hypothesize that it is the SLF of these optically thin low- and mid-level midlatitude clouds not shielded by overlying clouds that matters for ECS because the cloudtop temperature of these clouds is in the mixed-phase temperature range. Hence, the cloud phase at the cloud top of these clouds plays an important role in the TOA radiation budget. If the absorption of shortwave radiation over the Southern Ocean is correctly simulated, then SLF in other clouds does not matter for ECS. At least this is what the ECHAM6HAM2 results show because only in simulation ALL_ICE is significantly less shortwave radiation reflected back to space from Southern Ocean clouds and this is the only simulation in which ECS is significantly smaller than in all other simulations. In all other simulations sufficient or even too much shortwave radiation is reflected back to space from Southern Ocean clouds and all of them have similar values of ECS.

The reason why an underestimation of SLF in cloud types other than thin midlatitude clouds with cloud-top temperatures between 0 and $-35^{\circ} \mathrm{C}$ does not seem to matter is because radiative changes in clouds in the warm sector of extratropical cyclones are masked by ice clouds above them (Bodas-Salcedo et al., 2016). In addition, the tops of tropical deep convective and deep frontal clouds consist of ice and that will not change in a warmer climate. Low-level clouds in the tropics and subtropics already consist of liquid water and therefore their cloud phase will also not change in the future climate.

In our model, it is not only the cloud-phase feedback and the overall cloud feedback that matters for ECS. If this were the case, ECS should be largest in simulation ALL_LIQ, in which the cloud feedback parameter is highest. It seems that in simulation ALL_LIQ tropical deep convective clouds tend to aggregate, which causes a negative feedback by increasing the clear-sky area and with that the longwave emission from clear-sky regions to space (e.g., Hartmann and Larson, 2002; Mauritsen and Stevens, 2015). This negative feedback reduces the positive cloud feedback and causes the changes in the net cloud radiative effect and ECS to be the same in simulations REF and ALL_LIQ. Also in simulation NOCONV, 
in which we switched off the convection parameterization, SLF is higher than in simulation REF because of a reduced Wegener-Bergeron-Findeisen process. Again, ECS remains the same because of the smallest increase in cirrus cloud cover in this simulation that allows more clear-sky longwave radiation emission to space than in the reference simulation.

As discussed by Frey et al. (2017), while cloud-phase improvements in the extratropics affect ECS in their model, they do not seem to matter for the warming during the 21st century in the Community Earth System Model (CESM) because of compensating responses in ocean circulation. Whether this is also the case in other Earth system models, will be subject to future investigations.

Data availability. Model data are available from the authors upon request.

Competing interests. The authors declare that they have no conflict of interest.

Special issue statement. This article is part of the special issue "BACCHUS - Impact of Biogenic versus Anthropogenic emissions on Clouds and Climate: towards a Holistic UnderStanding (ACP/AMT/GMD inter-journal SI)". It is not associated with a conference.

Acknowledgements. The ECHAM-HAMMOZ model is developed by a consortium composed of ETH Zurich, Max Planck Institut für Meteorologie, Forschungszentrum Jülich, University of Oxford, the Finnish Meteorological Institute, and the Leibniz Institute for Tropospheric Research, and it is managed by the Center for Climate Systems Modeling (C2SM) at ETH Zurich. The research leading to these results has partly received funding from the Center for Climate System Modelling (C2SM) at ETH Zurich, the European Union's Seventh Framework Programme (FP7/2007-2013) project BACCHUS under grant agreement no. 603445, and the Swiss National Science Foundation (project number 200021_160177). We thank Thorsten Mauritsen, Trude Storelvmo, Alejandro Bodas-Salcedo, and the anonymous reviewers for useful comments and suggestions, Sylvaine Ferrachat for the help with earlier simulations on this topic, and Mark Zelinka and Thorsten Mauritsen for providing the radiative kernel used in this study.

The computing time for this work was supported by a grant from the Swiss National Supercomputing Centre (CSCS) under project ID s652 and from ETH Zurich. The data used are listed in the references and/or can be found here. CDNC climatology: Bennartz and Rausch (2016); MAC-LWP: Goddard Earth Sciences Data and Information Services Center (GES DISC, current hosting: http://disc.sci.gsfc.nasa.gov, last access: 20 June 2018); ATSR-2-AATSR v2.0: Poulsen et al. (2017); AVHRR-PM v3.0 (prototype): Stengel et al. (2017b); MODIS-AQUA collection 6.1: NASA Goddard (https://ladsweb.nascom.nasa.gov, last access: 20 June 2018).
Edited by: Holger Tost

Reviewed by: Trude Storelvmo and two anonymous referees

\section{References}

Abdul-Razzak, H. and Ghan, S. J.: A parameterization of aerosol activation: 2. Multiple aerosol types, J. Geophys. Res., 105, 68376844, 2000.

Adler, R. F., Huffman, G. J., Chang, A., Ferraro, R., Xie, P. P., Janowiak, J., Rudolf, B., Schneider, U., Curtis, S., Bolvin, D., Gruber, A., Susskind, J., Arkin, P., and Nelkin, E.: The version2 global precipitation climatology project (GPCP) monthly precipitation analysis (1979-present), J. Hydrometeorol., 4, 11471167, 2003.

Adler, R. F., Gu, G., and Huffman, G. J.: Estimating Climatological Bias Errors for the Global Precipitation Climatology Project (GPCP), J. Appl. Meteor. Clim., 51, 84-99, 2012.

Barrett, A. I., Hogan, R. J., and Forbes, R. M.: Why are mixed-phase altocumulus clouds poorly predicted by large-scale models? Part 1. Physical processes, J. Geophys. Res., 122, 9903-9926, 2017 a.

Barrett, A. I., Hogan, R. J., and Forbes, R. M.: Why are mixedphase altocumulus clouds poorly predicted by large-scale models? Part 2. Vertical resolution sensitivity and parameterization, J. Geophys. Res., 122, 9927-9944, 2017b.

Bennartz, R. and Rausch, J.: Cloud Droplet Number Concentration Climatology, available at: http://hdl.handle.net/1803/8374 (last access: 21 June 2018), 2016.

Bennartz, R. and Rausch, J.: Global and regional estimates of warm cloud droplet number concentration based on 13 years of AQUA-MODIS observations, Atmos. Chem. Phys., 17, 98159836, https://doi.org/10.5194/acp-17-9815-2017, 2017.

Block, K. and Mauritsen, T.: Forcing and feedback in the MPIESM-LR coupled model under abruptly quadrupled $\mathrm{CO}_{2}$, J. Adv. Model. Earth Syst., 5, 676-691, 2013.

Bodas-Salcedo, A.: Cloud condensate and radiative feedbacks at midlatitudes in an aquaplanet, Geophys. Res. Lett., 45, 36353643, https://doi.org/10.1002/2018GL077217, 2018.

Bodas-Salcedo, A., Webb, M. J., Bony, S., Chepfer, H., Dufresne, J. L., Klein, S. A., Zhang, Y., Marchand, R., Haynes, J. M., Pincus, R., and John, V. O.: COSP Satellite simulation software for model assessment, B. Am. Meteorol. Soc., 92, 1023-1043, 2011.

Bodas-Salcedo, A., Williams, K. D., Ringer, M. A., Beau, I., Cole, J. N. S., Dufresne, J.-L., Koshiro, T., Stevens, B., Wang, Z., and Yokohata, T.: Origins of the Solar Radiation Biases over the Southern Ocean in CFMIP2 Models, J. Climate, 27, 41-56, 2014.

Bodas-Salcedo, A., Andrews, T., Karmalkar, A. V., and Ringer, M. A.: Cloud liquid water path and radiative feedbacks over the Southern Ocean, Geophys. Res. Lett., 43, 10938-10946, 2016.

Bony, S., Stevens, B., Coppin, D., Becker, T., Reed, K. A., Voigt, A., and Medeiros, B.: Thermodynamic control of anvil cloud amount, P. Natl. Acad. Sci. USA, 113, 8927-8932, 2016.

Boucher, O., Randall, D., Artaxo, P., Bretherton, C., Feingold, G., Forster, P., Kerminen, V.-M., Kondo, Y., Liao, H., Lohmann, U., Rasch, P., Satheesh, S. K., Sherwood, S., Stevens, B., and Zhang, X.-Y.: Clouds and Aerosols, in: Climate Change 2013: The Physical Science Basis. Contribution of Working Group I to the Fifth Assessment Report of the Intergovernmental Panel on Climate Change, edited by: Stocker, T., Qin, D., Plattner, G.-K., Tignor, 
M., Allen, S. K., Boschung, J., Nauels, A., Xia, Y., Bex, V., and Midgley, P. M., 571-657, Cambridge Univ. Press, Cambridge, UK and New York, NY, USA, 2013.

Bourgeois, Q. and Bey, I.: Pollution transport efficiency toward the Arctic: Sensitivity to aerosol scavenging and source regions, J. Geophys. Res., 116, D08213, https://doi.org/10.1029/2010JD015096, 2011.

Brovkin, V., Boysen, L., Raddatz, T., Gayler, V., Loew, A., and Claussen, M.: Evaluation of vegetation cover and land-surface albedo in MPI-ESM CMIP5 simulations, J. Adv. Model. Earth Syst., 5, 48-57, 2013.

Ceppi, P., Hartmann, D. L., and Webb, M. J.: Mechanisms of the Negative Shortwave Cloud Feedback in Middle to High Latitudes, J. Climate, 29, 139-157, 2016.

Cess, R. D., Potter, G. L., Blanchet, J. P., Boer, G. J., Ghan, S. J., Kiehl, J. T., Letreut, H., Li, Z. X., Liang, X. Z., Mitchell, J. F. B., Morcrette, J. J., Randall, D. A., Riches, M. R., Roeckner, E., Schlese, U., Slingo, A., Taylor, K. E., Washington, W. M., Wetherald, R. T., and Yagai, I.: Interpretation of Cloud-Climate Feedback as Produced by 14 Atmospheric General Circulation Models, Science, 245, 513-516, 1989.

Collins, M., Knutti, R., Arblaster, J., Dufresne, J.-L., Fichefet, T., Friedlingstein, P., Gao, X., Gutowski, W. J., Johns, T., Krinner, G., Shongwe, M., Tebaldi, C., Weaver, A. J., and Wehner, M.: Long-term Climate Change: Projections, Commitments and Irreversibility, in: Climate Change 2013: The Physical Science Basis. Contribution of Working Group I to the Fifth Assessment Report of the Intergovernmental Panel on Climate Change, edited by: Stocker, T., Qin, D., Plattner, G.-K., Tignor, M., Allen, S. K., Boschung, J., Nauels, A., Xia, Y., Bex, V., and Midgley, P. M., 1029-1136, Cambridge Univ. Press, Cambridge, UK and New York, NY, USA, 2013.

Croft, B., Lohmann, U., Martin, R. V., Stier, P., Wurzler, S., Feichter, J., Posselt, R., and Ferrachat, S.: Aerosol sizedependent below-cloud scavenging by rain and snow in the ECHAM5-HAM, Atmos. Chem. Phys., 9, 4653-4675, https://doi.org/10.5194/acp-9-4653-2009, 2009.

Croft, B., Lohmann, U., Martin, R. V., Stier, P., Wurzler, S., Feichter, J., Hoose, C., Heikkilä, U., van Donkelaar, A., and Ferrachat, S.: Influences of in-cloud aerosol scavenging parameterizations on aerosol concentrations and wet deposition in ECHAM5-HAM, Atmos. Chem. Phys., 10, 1511-1543, https://doi.org/10.5194/acp-10-1511-2010, 2010.

Cziczo, D. J., Froyd, K. D., Hoose, C., Jensen, E. J., Diao, M. H., Zondlo, M. A., Smith, J. B., Twohy, C. H., and Murphy, D. M.: Clarifying the Dominant Sources and Mechanisms of Cirrus Cloud Formation, Science, 340, 1320-1324, 2013.

Dufresne, J.-L. and Bony, S.: An assessment of the primary sources of spread of global warming estimates from coupled atmosphereocean models, J. Climate, 21, 5135-5144, 2008.

Elsaesser, G. W., O’Dell, C. W., Lebsock, M. D., Bennartz, R., Greenwald, T. J., and Wentz, F. J.: The Multi-Sensor Advanced Climatology of Liquid Water Path (MAC-LWP), J. Climate, 30, 10193-10210, https://doi.org/10.1175/JCLI-D-16-0902.1, 2018.

Flato, G., Marotzke, J., Abiodun, B., Braconnot, P., Chou, S. C., Collins, W., Cox, P., Driouech, F., Emori, S., Eyring, V., Forest, C., Gleckler, P., Guilyardi, E., Jakob, C., Kattsov, V., Reason, C., and Rummukainen, M.: Evaluation of Climate Models, in: Climate Change 2013: The Physical Science Basis. Contribution of
Working Group I to the Fifth Assessment Report of the Intergovernmental Panel on Climate Change, edited by: Stocker, T., Qin, D., Plattner, G.-K., Tignor, M., Allen, S. K., Boschung, J., Nauels, A., Xia, Y., Bex, V., and Midgley, P. M.,741-866, Cambridge Univ. Press, Cambridge, UK and New York, NY, USA, 2013.

Forster, P. M., Andrews, T., Good, P., Gregory, J. M., Jackson, L. S., and Zelinka, M.: Evaluating adjusted forcing and model spread for historical and future scenarios in the CMIP5 generation of climate models, J. Geophys. Res., 118, 1139-1150, 2013.

Frey, W. R. and Kay, J. E.: The influence of extratropical cloud phase and amount feedbacks on climate sensitivity, Clim. Dynam., 50, 3097-3116, https://doi.org/10.1007/s00382-017-3796$5,2017$.

Frey, W. R., Maroon, E. A., Pendergrass, A. G., and Kay, J. E.: Do Southern Ocean Cloud Feedbacks Matter for 21st Century Warming?, Geophys. Res. Lett., 44, 12447-12456, 2017.

Gasparini, B., Meyer, A., Neubauer, D., Münch, S., and Lohmann, U.: Cirrus cloud properties as seen by the CALIPSO satellite and ECHAM-HAM global climate model, J. Climate, 31, 19832003, https://doi.org/10.1175/JCLI-D-16-0608.1, 2018.

Gettelman, A. and Sherwood, S. C.: Processes Responsible for Cloud Feedback, Current Climate Change Reports, 2, 179-189, 2016.

Gordon, N. D. and Klein, S. A.: Low-cloud optical depth feedback in climate models, J. Geophys. Res., 119, 6052-6065, 2014.

Gregory, J. M., Ingram, W. J., Palmer, M. A., Jones, G. S., Stott, P. A., Thorpe, R. B., Lowe, J. A., Johns, T. C., and Williams, K. D.: A new method for diagnosing radiative forcing and climate sensitivity, Geophys. Res. Lett., 31, L03205, https://doi.org/10.1029/2003GL018747, 2004.

Hartmann, D. L. and Larson, K.: An important constaint on tropical cloud - climate feedback, Geophys. Res. Lett., 29, 1951, https://doi.org/10.1029/2002GL015835, 2002.

Hoose, C., Lohmann, U., Bennartz, R., Croft, B., and Lesins, G.: Global simulations of aerosol processing in clouds, Atmos. Chem. Phys., 8, 6939-6963, https://doi.org/10.5194/acp-8-69392008, 2008.

Hoose, C., Kristjánsson, J. E., Iversen, T., Kirkevåg, A., Seland, Ø., and Gettelman, A.: Constraining cloud droplet number concentration in GCMs suppresses the aerosol indirect effect, Geophys. Res. Lett., 36, L12807, https://doi.org/10.1029/2009GL038568, 2009.

Iacono, M. J., Delamere, J. S., Mlawer, E. J., Shephard, M. W., Clough, S. A., and Collins, W. D.: Radiative forcing by long-lived greenhouse gases: Calculations with the AER radiative transfer models, J. Geophys. Res., 113, D13103, https://doi.org/10.1029/2008jd009944, 2008.

Kärcher, B.: Cirrus Clouds and Their Response to Anthropogenic Activities, Current Climate Change Reports, 3, 45-57, 2017.

Kay, J. E., Wall, C., Yettella, V., Medeiros, B., Hannay, C., Caldwell, P., and Bitz, C.: Global Climate Impacts of Fixing the Southern Ocean Shortwave Radiation Bias in the Community Earth System Model (CESM), J. Climate, 29, 4617-4636, 2016.

Kinne, S., O’Donnel, D., Stier, P., Kloster, S., Zhang, K., Schmidt, H., Rast, S., Giorgetta, M., Eck, T., and Stevens, B.: MAC-v1: A new global aerosol climatology for climate studies, J. Adv. Model. Earth Sy., 5, 704-740, 2013. 
Knutti, R. and Rugenstein, M. A. A.: Feedbacks, climate sensitivity and the limits of linear models, Philos. T. R. Soc. A, 373, 2054, https://doi.org/10.1098/rsta.2015.0146, 2015.

Komurcu, M., Storelvmo, T., Tan, I., Lohmann, U., Yun, Y., Penner, J. E., Wang, Y., Liu, X., and Takemura, T.: Intercomparison of the cloud water phase among global climate models, J. Geophys. Res., 119, 3372-3400, 2014.

Korolev, A.: Limitations of the Wegener-Bergeron-Findeisen mechanism in the evolution of mixed-phase clouds, J. Atmos. Sci., 64, 3372-3375, 2007.

Krämer, M., Rolf, C., Luebke, A., Afchine, A., Spelten, N., Costa, A., Meyer, J., Zöger, M., Smith, J., Herman, R. L., Buchholz, B., Ebert, V., Baumgardner, D., Borrmann, S., Klingebiel, M., and Avallone, L.: A microphysics guide to cirrus clouds - Part 1: Cirrus types, Atmos. Chem. Phys., 16, 3463-3483, https://doi.org/10.5194/acp-16-3463-2016, 2016.

Lebsock, M. and Su, H.: Application of active spaceborne remote sensing for understanding biases between passive cloud water path retrievals, J. Geophys. Res., 119, 8962-8979, 2014.

Li, J.-L. F., Waliser, D. E., Chen, W.-T., Guan, B., Kubar, T., Stephens, G., Ma, H.-Y., Deng, M., Donner, L., Seman, C., and Horowitz, L.: An observationally based evaluation of cloud ice water in CMIP3 and CMIP5 GCMs and contemporary reanalyses using contemporary satellite data, J. Geophys. Res., 117, D16105, https://doi.org/10.1029/2012JD017640, 2012.

Lin, H. and Leaitch, W. R.: Development of an in-cloud aerosol activation parameterization for climate modelling, in: Proceedings of the WMO Workshop on Measurement of Cloud Properties for Forecasts of Weather, Air Quality and Climate, 328-335, World Meteorol. Organ., Geneva, 1997.

Lin, S. J. and Rood, R. B.: Multidimensional flux-form semiLagrangian transport schemes, Mon. Weather Rev., 124, 20462070, 1996.

Loeb, N. G., Wielicki, B. A., Doelling, D. R., Smith, G. L., Keyes, D. F., Kato, S., Manalo-Smith, N., and Wong, T.: Toward Optimal Closure of the Earth's Top-of-Atmosphere Radiation Budget, J. Climate, 22, 748-766, 2009.

Loeb, N. G., Doelling, D. R., Wang, H. L., Su, W. Y., Nguyen, C., Corbett, J. G., Liang, L. S., Mitrescu, C., Rose, F. G., and Kato, S.: Clouds and the Earth's Radiant Energy System (CERES) Energy Balanced and Filled (EBAF) Top-of-Atmosphere (TOA) Edition-4.0 Data Product, J. Climate, 31, 895-918, 2018.

Lohmann, U.: Sensitivität des Modellklimas eines globalen Zirkulationsmodells der Atmosphäre gegenüber Änderungen der Wolkenmikrophysik, PhD thesis, Max Planck Institute for Meteorology, Hamburg, Germary, 1996.

Lohmann, U.: Possible aerosol effects on ice clouds via contact nucleation, J. Atmos. Sci., 59, 647-656, 2002.

Lohmann, U.: Global anthropogenic aerosol effects on convective clouds in ECHAM5-HAM, Atmos. Chem. Phys., 8, 2115-2131, https://doi.org/10.5194/acp-8-2115-2008, 2008.

Lohmann, U. and Ferrachat, S.: Impact of parametric uncertainties on the present-day climate and on the anthropogenic aerosol effect, Atmos. Chem. Phys., 10, 11373-11383, https://doi.org/10.5194/acp-10-11373-2010, 2010.

Lohmann, U. and Hoose, C.: Sensitivity studies of different aerosol indirect effects in mixed-phase clouds, Atmos. Chem. Phys., 9, 8917-8934, https://doi.org/10.5194/acp-9-8917-2009, 2009.
Lohmann, U. and Kärcher, B.: First interactive simulations of cirrus clouds formed by homogeneous freezing in the ECHAM GCM, J. Geophys. Res., 107, AAC 8-1-AAC 8-13, https://doi.org/10.1029/2001JD000767, 2002.

Lohmann, U. and Roeckner, E.: The influence of cirrus cloudradiative forcing on climate and climate sensitivity in a general circulation model, J. Geophys. Res., 100, 16305-16323, 1995.

Lohmann, U. and Roeckner, E.: Design and performance of a new cloud microphysics scheme developed for the ECHAM general circulation model, Clim. Dynam., 12, 557-572, 1996.

Lohmann, U., Stier, P., Hoose, C., Ferrachat, S., Kloster, S., Roeckner, E., and Zhang, J.: Cloud microphysics and aerosol indirect effects in the global climate model ECHAM5-HAM, Atmos. Chem. Phys., 7, 3425-3446, https://doi.org/10.5194/acp-7-34252007, 2007.

Marcolli, C., Gedamke, S., Peter, T., and Zobrist, B.: Efficiency of immersion mode ice nucleation on surrogates of mineral dust, Atmos. Chem. Phys., 7, 5081-5091, https://doi.org/10.5194/acp7-5081-2007, 2007.

Matus, A. V. and L'Ecuyer, T. S.: The role of cloud phase in Earth's radiation budget, J. Geophys. Res., 122, 2559-2578, 2017.

Mauritsen, T. and Stevens, B.: Missing iris effect as a possible cause of muted hydrological change and high climate sensitivity in models, Nat. Geosci., 8, 346-351, 2015.

McCoy, D. T., Hartmann, D. L., Zelinka, M. D., Ceppi, P., and Grosvenor, D. P.: Mixed-phase cloud physics and Southern Ocean cloud feedback in climate models, J. Geophys. Res., 120, 9539-9554, 2015.

Meehl, G. A., Stocker, T. F., Collins, W. D., Friedlingstein, P., Gaye, A. T., Gregory, J. M., Kitoh, A., Knutti, R., Murphy, J. M., Noda, A., Raper, S. C. B., Watterson, I. G., Weaver, A. J., and Zhao, Z.-C.: Global climate projections, in: Climate Change 2007: The Physical Science Basis. Contribution of Working Group I to the Fourth Assessment Report of the Intergovernmental Panel on Climate Change, edited by: Solomon, S., Qin, D., Manning, M., Chen, Z., Marquis, M., Averyt, K. B., Tignor, M., and Miller, H. L., 747-846, Cambridge Univ. Press, Cambridge, UK and New York, NY, USA, 2007.

Mitchell, J. F. B., Senior, C. A., and Ingram, W. J.: $\mathrm{CO}_{2}$ and Climate - A Missing Feedback, Nature, 341, 132-134, 1989.

Neubauer, D., Lohmann, U., Hoose, C., and Frontoso, M. G.: Impact of the representation of marine stratocumulus clouds on the anthropogenic aerosol effect, Atmos. Chem. Phys., 14, 1199712022, https://doi.org/10.5194/acp-14-11997-2014, 2014.

Pincus, R. and Stevens, B.: Paths to accuracy for radiation parameterizations in atmospheric models, J. Adv. Model. Earth Sy., 5, 225-233, 2013.

Platnick, S., King, M. D., Meyer, K. G., Wind, G., Amarasinghe, N., Marchant, B., Arnold, G. T., Zhang, Z. B., Hubanks, P. A., Ridgway, B., and Riedi, J.: MODIS Cloud Optical Properties: User Guide for the Collection 6 Level2 MOD06/MYD06 Product and Associated Level-3 Datasets, NASA, available at: https://modis-atmos.gsfc.nasa.gov/_docs/ C6MOD06OPUserGuide.pdf (last access: 20 June 2018), 2015.

Platnick, S., Meyer, K. G., King, M. D., Wind, G., Amarasinghe, N., Marchant, B., Arnold, G. T., Zhang, Z., Hubanks, P. A., Holz, R. E., Yang, P., Ridgway, W. L., and Riedi, J.: The MODIS Cloud Optical and Microphysical Products: Collection 6 Updates and 
Examples From Terra and Aqua, IEEE T. Geosci. Remote Sens., 55, 502-525, 2017.

Poulsen, C., McGarragh, G., Thomas, G., Christensen, M., Povey, A., Grainger, D., Proud, S., and Hollmann, R.: ESA Cloud Climate Change Initiative (ESA Cloud_cci) data: Cloud_cci ATSR2-AATSR L3C/L3U/L2 CLD_PRODUCTS v2.0, Deutscher Wetterdienst (DWD) and Rutherford Appleton Laboratory (Dataset Producer), 2017.

Pruppacher, H. R. and Klett, J. D.: Microphysics of Clouds and Precipitation, Kluwer Acad., Norwell, Mass., 1997.

Randall, D., Wood, R., Bony, S., Colman, R., Fichefet, T., Fyfe, J., Kattsov, V., Pitman, A., Shukla, J., Srinivasan, J., Stouffer, R., Sumi, A., and Tayler, K.: Climate Models and Their Evaluation, in: Climate Change 2007: The Scientific Basis. Contribution of working group I to the Forth Assessment Report of the Intergovernmental Panel on Climate Change, edited by: Solomon, S., Qin, D., Manning, M., Chen, Z., Marquis, M., Averyt, K. B., Tignor, M., and Miller, H. L., 589-662, Cambridge Univ. Press, Cambridge, UK and New York, NY, USA, 2007.

Reick, C. H., Raddatz, T., Brovkin, V., and Gayler, V.: Representation of natural and anthropogenic land cover change in MPIESM, J. Adv. Model. Earth Sy., 5, 459-482, 2013.

Schultz, M. G., Stadtler, S., Schröder, S., Taraborrelli, D., Franco, B., Krefting, J., Henrot, A., Ferrachat, S., Lohmann, U., Neubauer, D., Siegenthaler-Le Drian, C., Wahl, S., Kokkola, H., Kühn, T., Rast, S., Schmidt, H., Stier, P., Kinnison, D., Tyndall, G. S., Orlando, J. J., and Wespes, C.: The chemistry-climate model ECHAM6.3-HAM2.3-MOZ1.0, Geosci. Model Dev., 11, 1695-1723, https://doi.org/10.5194/gmd-11-1695-2018, 2018.

Seethala, C. and Horvath, A.: Global assessment of AMSR$\mathrm{E}$ and MODIS cloud liquid water path retrievals in warm oceanic clouds, J. Geophys. Res., 115, D13202, https://doi.org/10.1029/2009JD012662, 2010.

Seifert, A. and Beheng, K. D.: A two-moment cloud microphysics parameterization for mixed-phase clouds. Part 1: Model description, Meteorol. Atmos. Phys., 92, 45-66, 2006.

Shell, K. M., Kiehl, J. T., and Shields, C. A.: Using the radiative kernel technique to calculate climate feedbacks in NCAR's Community Atmospheric Model, J. Climate, 21, 2269-2282, 2008.

Soden, B. J., Wetherald, R. T., Stenchikov, G. L., and Robock, A.: Clobal cooling after the eruption of Mount Pinatubo: A test of climate feedback by water vapor, Science, 296, 727-730, 2002.

Soden, B. J., Held, I. M., Colman, R., Shell, K. M., Kiehl, J. T., and Shields, C. A.: Quantifying Climate Feedbacks Using Radiative Kernels, J. Climate, 21, 3504-3520, 2008.

Solomon, S., Qin, D., Manning, M., Alley, R. B., Berntsen, T., Bindoff, N. L., Chen, Z., Chidthaisong, A., Gregory, J. M., Hegerl, G. C., Heimann, H., Hewitson, B., Hoskins, B. J., Joos, F., Jouzel, J., Kattsov, V., Lohmann, U., Matsuno, T., Molina, M., Nicholls, N., Overpeck, J., Raga, G., Ramaswamy, V., Ren, J., Rusticucci, M., Somerville, R., Stocker, T. F., Whetton, P., A., W. R., and Wratt, D.: Technical Summary, in: Climate Change 2007: The Physical Science Basis. Contribution of Working Group I to the Fourth Assessment Report of the Intergovernmental Panel on Climate Change, edited by: Solomon, S., Qin, D., Manning, M., Chen, Z., Marquis, M., Averyt, K. B., Tignor, M., and Miller, H. L., Cambridge Univ. Press, Cambridge, UK and New York, NY, USA, 2007.
Spichtinger, P. and Krämer, M.: Tropical tropopause ice clouds: a dynamic approach to the mystery of low crystal numbers, Atmos. Chem. Phys., 13, 9801-9818, https://doi.org/10.5194/acp13-9801-2013, 2013.

Stengel, M., Stapelberg, S., Sus, O., Schlundt, C., Poulsen, C., Thomas, G., Christensen, M., Carbajal Henken, C., Preusker, R., Fischer, J., Devasthale, A., Willén, U., Karlsson, K.-G., McGarragh, G. R., Proud, S., Povey, A. C., Grainger, R. G., Meirink, J. F., Feofilov, A., Bennartz, R., Bojanowski, J. S., and Hollmann, R.: Cloud property datasets retrieved from AVHRR, MODIS, AATSR and MERIS in the framework of the Cloud_cci project, Earth Syst. Sci. Data, 9, 881-904, https://doi.org/10.5194/essd9-881-2017, 2017a.

Stengel, M., Sus, O., Stapelberg, S., Schlundt, C., Poulsen, C., and Hollmann, R.: ESA Cloud Climate Change Initiative (ESA Cloud_cci), Deutscher Wetterdienst (DWD), Offenbach, Germany, 2017b.

Stephens, G. L., Li, J., Wild, M., Clayson, C. A., Loeb, N., Kato, S., L'Ecuyer, T., Stackhouse Jr., P. W., Lebsock, M., and Andrews, T.: An update on Earth's energy balance in light of the latest global observations, Nat. Geosci., 5, 691-696, https://doi.org/10.1038/ngeo1580, 2012.

Stevens, B., Giorgetta, M., Esch, M., Mauritsen, T., Crueger, T., Rast, S., Salzmann, M., Schmidt, H., Bader, J., Block, K., Brokopf, R., Fast, I., Kinne, S., Kornblueh, L., Lohmann, U., Pincus, R., Reichler, T., and Roeckner, E.: Atmospheric component of the MPI-M Earth System Model: ECHAM6, J. Adv. Model. Earth Sy., 5, 146-172, 2013.

Stevens, B., Fiedler, S., Kinne, S., Peters, K., Rast, S., Müsse, J., Smith, S. J., and Mauritsen, T.: MACv2-SP: a parameterization of anthropogenic aerosol optical properties and an associated Twomey effect for use in CMIP6, Geosci. Model Dev., 10, 433452, https://doi.org/10.5194/gmd-10-433-2017, 2017.

Stier, P.: Limitations of passive remote sensing to constrain global cloud condensation nuclei, Atmos. Chem. Phys., 16, 6595-6607, https://doi.org/10.5194/acp-16-6595-2016, 2016.

Stier, P., Feichter, J., Kinne, S., Kloster, S., Vignati, E., Wilson, J., Ganzeveld, L., Tegen, I., Werner, M., Balkanski, Y., Schulz, M., Boucher, O., Minikin, A., and Petzold, A.: The aerosol-climate model ECHAM5-HAM, Atmos. Chem. Phys., 5, 1125-1156, https://doi.org/10.5194/acp-5-1125-2005, 2005.

Stubenrauch, C. J., Rossow, W. B., Kinne, S., Ackerman, S., Cesana, G., Chepfer, H., Girolamo, L. D., Getzewich, B., Guignard, A., Heidinger, A., Maddux, B. C., Menzel, W. P., Minnis, P., Pearl, C., Platnick, S., Poulsen, C., Riedi, J., Sun-Mack, S., Walther, A., Winker, D., Zeng, S., and Zhao, G.: Assessment of Global Cloud Datasets from Satellites: Project and Database Initiated by the GEWEX Radiation Panel, B. Am. Meteorol. Soc., 94, 1031-1049, 2013.

Sundqvist, H., Berge, E., and Kristjánsson, J. E.: Condensation and Cloud Parameterization Studies with a Mesoscale Numerical Weather Prediction Model, Mon. Weather Rev., 117, 1641-1657, 1989.

Susskind, J., Piraino, P., Rokke, L., Iredell, T., and Mehta, A.: Characteristics of the TOVS Pathfinder Path A dataset, B. Am. Meteorol. Soc., 78, 1449-1472, 1997.

Tan, I., Storelvmo, T., and Zelinka, M. D.: Observational constraints on mixed-phase clouds imply higher climate sensitivity, Science, 352, 224-227, 2016. 
Terai, C. R., Bretherton, C. S., Wood, R., and Painter, G.: Aircraft observations of aerosol, cloud, precipitation, and boundary layer properties in pockets of open cells over the southeast Pacific, Atmos. Chem. Phys., 14, 8071-8088, https://doi.org/10.5194/acp14-8071-2014, 2014.

Terai, C. R., Klein, S. A., and Zelinka, M. D.: Constraining the lowcloud optical depth feedback at middle and high latitudes using satellite observations, J. Geophys. Res., 121, 9696-9716, 2016.

Tiedtke, M.: A Comprehensive Mass Flux Scheme for Cumulus Parameterization in Large-Scale Models, Mon. Weather Rev., 117, 3040-3061, 1989.

Vial, J., Dufresne, J.-L., and Bony, S.: On the interpretation of intermodel spread in CMIP5 climate sensitivity estimates, Clim. Dynam., 41, 3339-3362, 2013.

Webb, M. J., Lock, A. P., Bretherton, C. S., Bony, S., Cole, J. N. S., Idelkadi, A., Kang, S. M., Koshiro, T., Kawai, H., Ogura, T., Roehrig, R., Shin, Y., Mauritsen, T., Sherwood, S. C., Vial, J., Watanabe, M., Woelfle, M. D., and Zhao, M.: The impact of parametrized convection on cloud feedback, Philos. T. R. Soc. A, 373, 2054, https://doi.org/10.1098/rsta.2014.0414, 2015.

Wernli, H., Boettcher, M., Joos, H., Miltenberger, A. K., and Spichtinger, P.: A trajectory-based classification of ERA-Interim ice clouds in the region of the North Atlantic storm track, Geophys. Res. Lett., 43, 6657-6664, 2016.

Williams, K. D., Bodas-Salcedo, A., Déqué, M., Fermepin, S., Medeiros, B., Watanabe, M., Jakob, C., Klein, S. A., Senior, C. A., and Williamson, D. L.: The Transpose-AMIP II Experiment and Its Application to the Understanding of Southern Ocean Cloud Biases in Climate Models, J. Climate, 26, 32583274, 2013.

Wood, R.: Drizzle in stratocumulus: Observations and model results, in: 11th AMS conference on cloud physics, Amer. Meteorol. Soc., Ogden, Utah, 2002.

Wood, R., O, K.-T., Bretherton, C. S., Mohrmann, J., Albrecht, B. A., Zuidema, P., Ghate, V., Schwartz, C., Eloranta, E., Glienke, S., Shaw, R. A., Fugal, J., and Minnis, P.: Ultraclean Layers and Optically Thin Clouds in the Stratocumulus-to-Cumulus Transition. Part I: Observations, J. Atmos. Sci., 75, 1631-1652, https://doi.org/10.1175/JAS-D-17-0213.1, 2018.
Yokohata, T., Webb, M. J., Collins, M., Williams, K. D., Yoshimori, M., Hargreaves, J. C., and Annan, J. D.: Structural Similarities and Differences in Climate Responses to $\mathrm{CO}_{2}$ Increase between Two Perturbed Physics Ensembles, J. Climate, 23, 1392-1410, https://doi.org/10.1175/2009JCLI2917.1, 2010.

Zelinka, M. D., Klein, S. A., and Hartmann, D. L.: Computing and Partitioning Cloud Feedbacks Using Cloud Property Histograms. Part I: Cloud Radiative Kernels, J. Climate, 25, 37153735, https://doi.org/10.1175/JCLI-D-11-00248.1, 2012a.

Zelinka, M. D., Klein, S. A., and Hartmann, D. L.: Computing and Partitioning Cloud Feedbacks Using Cloud Property Histograms. Part II: Attribution to Changes in Cloud Amount, Altitude, and Optical Depth, J. Climate, 25, 3736-3754, 2012b.

Zelinka, M. D., Zhou, C., and Klein, S. A.: Insights from a refined decomposition of cloud feedbacks, Geophys. Res. Lett., 43, 9259-9269, 2016.

Zelinka, M. D., Randall, D. A., Webb, M. J., and Klein, S. A.: Clearing clouds of uncertainty, Nat. Clim. Change, 7, 674-678, https://doi.org/10.1038/nclimate3402, 2017.

Zhang, K., O’Donnell, D., Kazil, J., Stier, P., Kinne, S., Lohmann, U., Ferrachat, S., Croft, B., Quaas, J., Wan, H., Rast, S., and Feichter, J.: The global aerosol-climate model ECHAM-HAM, version 2: sensitivity to improvements in process representations, Atmos. Chem. Phys., 12, 8911-8949, https://doi.org/10.5194/acp-12-8911-2012, 2012.

Zhou, C., Dessler, A. E., Zelinka, M. D., Yang, P., and Wang, T.: Cirrus feedback on inter-annual climate fluctuations, Geophys. Res. Lett., 41, 9166-9173, 2014. 